\title{
Thermal Structure due to Solid-State Flow in the Mantle Wedge Beneath Arcs
}

\author{
Peter B. Kelemen \\ Dept. of Geology \& Geophysics, Woods Hole Oceanographic Institution, Woods Hole, Massachusetts \\ Jennifer L. Rilling and E.M. Parmentier \\ Dept. of Geological Sciences, Brown University, Providence, Rhode Island \\ Luc Mehl and Bradley R. Hacker \\ Dept. of Geological Sciences \& Institute for Crustal Studies, University of California, Santa Barbara, California
}

\begin{abstract}
We summarize petrological and seismic constraints on the temperature of arc lower crust and shallow mantle, and show that published thermal models are inconsistent with these constraints. We then present thermal models incorporating temperature-dependent viscosity, using widely accepted values for activation energy and asthenospheric viscosity. These produce thin thermal boundary layers in the wedge corner, and an overall thermal structure that is consistent with other temperature constraints. Some of these models predict partial melting of subducted sediment and/or basalt, even though we did not incorporate the effect of shear heating We obtain these results for subduction of $50 \mathrm{Myr}$ old oceanic crust at $60 \mathrm{~km} / \mathrm{Myr}$, and even for subduction of $80 \mathrm{Myr}$ old crust at $80 \mathrm{~km} / \mathrm{Myr}$, suggesting that melting of subducted crust may not be not restricted to slow subduction of young oceanic crust.
\end{abstract}

\section{INTRODUCTION}

Modern thermal models suggest that subducted sediments, and subducted oceanic crust that is more than 20 million years old, are unlikely to partially melt beneath arcs undergoing near-steady state subduction. These calculations are essentially of three types: (1) analytical approximations including various assumptions about coupling between the subducted crust and the overlying mantle and about convection in the mantle wedge [e.g., Davies, 1999; Molnar and England, 1995; Molnar and England, 1990], (2) purely plate-driven models with uniform viscosity, in which the thermal regime is calculated numerically using analytical expressions for corner flow in the mantle wedge, with model results depending on various input parameters including the thickness of the arc "lithosphere" and the depth of coupling between subducting crust and overlying mantle [e.g., Peacock, 2002; Peacock and Hyndman, 1999; Peacock and Wang, 1999; Iwamori, 1997; Peacock, 1996; Ponko and Peacock, 1995; Peacock et al., 1994; Pearce et al., 1992; Peacock, 1991;
Peacock, 1990a; Peacock, 1990b], and (3) dynamic models in which the mantle flow field as well as the thermal regime are calculated numerically, with model results depending on parameters such as thermal buoyancy, chemical buoyancy and mantle viscosity [van Keken et al., 2002; Furukawa and Tatsumi, 1999; Kincaid and Sacks, 1997; Furukawa, 1993a; Furukawa, 1993b; Davies and Stevenson, 1992]. These models differ in many respects, but most agree that subduction of oceanic crust that is more than 20 million years old at down-dip rates greater than $20 \mathrm{~km} / \mathrm{Myr}$ will not produce temperatures at the top of the subducting plate that are high enough to allow fluid-saturated melting of sediment or basalt. The sole exceptions are recent models by Conder et al. [2002] which, like ours, incorporate only temperature-dependent viscosity, and a model by van Keken et al. which incorporates both temperature- and stress-dependent viscosity.

In contrast, a variety of geochemical and petrological inferences suggest that partial melting of subducted sediment and/or basalt is common in many 
arcs. These inferences may be divided into two main lines of reasoning.

(1) Partial melting of subducted metabasalt (or metagabbro) at eclogite facies conditions is inferred based on the similarity of trace element patterns in rare, primitive andesites with partial melts of eclogite [e.g., Defant and Kepezhinskas, 2001; Grove et al., 2001; Tatsumi et al., 2001; Yogodzinski et al., 2001; Rapp et al., 1999; Yogodzinski and Kelemen, 1998; Yogodzinski et al., 1995; Yogodzinski et al., 1994;; Defant and Drummond, 1990; Drummond and Defant, 1990; Kay, 1978]. Such lavas are primarily observed where subduction rates are slow, and/or the subducting oceanic crust is young $(<20$ million years old), and/or the subducting plate terminates along strike allowing heating from the side as well as from the top [Yogodzinski et al., 2001; Defant and Drummond, 1990]. Thus, it is commonly inferred that this evidence applies mainly or exclusively to unusual thermal conditions, and does not require modification of 2D, steady-state thermal models for arcs.

(2) Efficient recycling of elements such as Th and Be from subducted sediments into arc magmas in most arcs worldwide is inferred from correlation of, e.g., Th/La with $\mathrm{Pb}$ and $\mathrm{Nd}$ isotope ratios in arc lavas [Class et al., 2000; Elliott et al., 1997; Hawkesworth et al., 1997], and from correlation of Th enrichment in arc lavas with the flux of subducted, sedimentary $\mathrm{Th}$ [Plank and Langmuir, 1998; Plank and Langmuir, 1993]. Because Th and $\mathrm{Be}$ are relatively insoluble in aqueous fluids, even under simulated subduction zone conditions, but are highly mobile incompatible elements during partial melting of both metasediments and metabasalt, it is argued that their efficient recycling requires melting of subducting sediment [e.g., Johnson and Plank, 1999; Brenan et al., 1995a; Brenan et al., 1995b;]. Unlike inference (1), this second line of reasoning applies to lavas formed via subduction of relatively old oceanic crust $(>20$ million years old). For example, a sediment melt component is apparently important in the Marianas arc, where subducting crust is more than $140 \mathrm{Ma}$ [e.g., Elliott et al., 1997].

These two types of evidence are often treated separately, and indeed inference (2) is often summarized with the aphorism "sediments melt, basalts dehydrate". However, the solidus temperatures for fluid-saturated metasediment and metabasalt are very similar [e.g., Johnson and Plank,
1999; Schmidt and Poli, 1998; Nichols et al., 1994]. Thus, geochemical data support the inference that partial melting of subducted sediment and/or basalt is common in present-day subduction zones.

The main objection to the conclusion that partial melting of subducted sediment and/or basalt is common comes from the thermal models cited in the first paragraph of this section. This has led to a longstanding disagreement, with one group confident that thermal models rule out melting in most subduction zones, and another group maintaining that "slab melting" occurs in the same subduction zones. Debate has largely centered on geochemical arguments, particularly ongoing research into the possibility that super-critical, Na-rich aqueous fluids have transport properties for elements such as Th which are very similar to the transport properties of melts [e.g., Keppler, 1996; Plank, 1996]. However, incorporating temperature-dependent viscosity into thermal models may explain "slab melting" [e.g., van Keken et al., 2002], Appendix B, and this paper). In general, thermal models for arcs deserve more intensive investigation.

In the course of the debate over "slab melting", some useful constraints may have been temporarily overlooked. First, thermal models predict temperatures in the uppermost mantle and at the base of arc crust that are hundreds of degrees lower than petrological estimates of temperature at these depths (Figure 1). Magmas and metamorphic rocks formed at these shallow depths reach the surface with relatively little modification, permitting more robust pressure and temperature estimates than those inferred for partial melting deep in subduction zones. (For references, please see caption to Figure 1).

Because arcs are magmatically active, and crystallizing melt lenses do not have to lie on a steady-state geotherm, it could be that the PT estimates for magmas and metamorphosed igneous rocks need not coincide with the steady-state thermal structure predicted in models (Figure 2). However, our second point is that thermal models do not account well for the shape of low velocity anomalies in the mantle wedge beneath arcs. Observation of a $6 \%$ low P-wave velocity anomaly at the base of arc crust for long distances along the strike of the NE Japan and Tonga arcs [e.g., Zhao et al., 1997; Zhao et al., 1992a]) suggests to us that melt is present in the mantle below a "permeability barrier" at the base of arc crust. Because this is observed over long distances along strike, reasoning that "almost everywhere" is indicative of "nearly all the time", we infer that melt is present near the base of the crust at steady state. 
Third, a key constraint used in all thermal models is that below a specified depth (40 to $100 \mathrm{~km}$ ) the subducting plate and the overlying mantle wedge are mechanically coupled. However, this assumption is apparently inconsistent with arc topography and gravity data, which are better fit with a weak coupling between the subducting plate and the overlying mantle, implying a low viscosity mantle wedge [Billen and Gurnis, 2001; Zhong and Gurnis, 1992].

Fourth, the difference between predicted, steady state temperatures in subduction zones and the fluidsaturated solidii for metasediment and metabasalt is small; it may be as narrow as $50{ }^{\circ} \mathrm{C}$ [e.g., Nichols et al., 1994]. Also, the fluid-saturated solidii are not precisely determined, and have poorly quantified compositional dependence (e.g., discussion in [Johnson and Plank, 1999]). Thus, relatively small changes in thermal models, which make them consistent with PT constraints from the lower crust and uppermost mantle, might also lead to a resolution of the apparent paradox in which geochemistry suggests partial melting of subducted sediment and basalt, while thermal models appear to rule this out.

This paper reviews PT estimates for mantle/melt equilibration and for metamorphic rocks at the base of arc crust, including new thermobarometric data for the Talkeetna arc section in Alaska, and then presents thermal models that are consistent with these PT estimates. We show that, with a temperaturedependent rheology, cooling of material in the mantle wedge causes this material to adhere to the subducting plate, advectively removing part of the thermal boundary layer in the wedge corner, provided the thermal activation energy for mantle deformation is sufficiently large $\left(Q /\left(R T_{\infty}\right) \geq 10\right.$, where $T_{\infty}$ is the asthenospheric temperature). Also, when the asthenospheric viscosity is sufficiently low $\left(\sim 10^{17} \mathrm{~Pa} \mathrm{~s}\right)$, a density current carries relatively cold, dense material downward along the slab, further thinning the thermal boundary layer. Entrainment of cold, viscous material with the subducting plate, and convective flow, both drive enhanced return flow of hot material diagonally upward into the wedge corner. Thinning of thermal boundary layers and enhanced return flow raise temperatures at the top of the subducting plate above the fluid-saturated solidus for metabasalt and metasediment. Even though our models do not include any shear heating along the subduction zone, thermal models that yield subduction zone temperatures higher than the fluid saturated solidus arise for widely accepted values for mantle viscosity and thermal activation energy are used, and for subduction of oceanic lithosphere as old as $80 \mathrm{Myr}$ at a rate as high as $80 \mathrm{~km} / \mathrm{yr}$, suggesting that melting of fluid-saturated subducted sediment or basalt in normal, steady-state subduction may be inevitable, rather than impossible.

\section{PRESSURE AND TEMPERATURE IN THE SHALLOW MANTLE AND LOWER CRUST BENEATH ARCS}

\section{2a. Magma/Mantle Equilibration at High \\ Temperature and low Pressure}

Over the past decade, methods have been developed for estimating the composition of partial melts of mantle peridotite as a function of the depth and temperature of melting [Kinzler, 1997; Kinzler and Grove, 1993; Kinzler and Grove, 1992b; Langmuir et al., 1992]. These methods can constrain the final depth and temperature at which a given, mantle-derived melt, might have equilibrated with peridotite. This is particularly straightforward for basalts with known, low $\mathrm{H}_{2} \mathrm{O}$-content. For such lavas in the southern Oregon Cascades and in Indonesia, last equilibration with the mantle was $~ 1290$ to $1450^{\circ} \mathrm{C}$ and 1 to $2 \mathrm{GPa}$ [Elkins Tanton et al., 2001; Sisson and Bronto, 1998]. As shown in Figure 1, Kinzler \& Grove [Kinzler and Grove, 1993; Kinzler and Grove, 1992a] estimate uncertainties of $0.25 \mathrm{GPa}$ and $25^{\circ} \mathrm{C}$ for such estimates. Similarly, Tatsumi et al. [1983] conducted phase equilibrium experiments to determine the conditions at which primitive lavas from NE Japan could have equilibrated with mantle peridotite, over a range of possible $\mathrm{H}_{2} \mathrm{O}$-contents. They also inferred conditions of $\sim 1325$ to $1360^{\circ} \mathrm{C}$ and 1 to $2 \mathrm{GPa}$. Similar conclusions have also been reached in phase equilibrium studies of primitive, high aluminum basalts [Draper and Johnston, 1992; Bartels et al., 1991].

No published thermal models for subduction zones predict such high temperatures in the uppermost mantle, near the base of the arc crust (Figure 1). Instead, all but one study predict temperatures less than $900^{\circ} \mathrm{C}$ at depths of $45 \mathrm{~km}(\sim 1.5 \mathrm{GPa})$ beneath an arc. The exception is the recent paper by van Keken et al. [van Keken et al., 2002], who used a stress and temperature-dependent viscosity in the mantle wedge, and predicted temperatures of $\sim 950$ to $1000^{\circ} \mathrm{C}$ at $45 \mathrm{~km}$ beneath $\mathrm{NE}$ Japan and the Cascades. It is instructive to extend this comparison by asking, at what depth beneath the arc do thermal models predict temperatures of $1300^{\circ} \mathrm{C}$ or more? The shallowest $1300^{\circ} \mathrm{C}$ isotherms are at $\sim 65 \mathrm{~km}$ in the NE Japan and Cascades models of van Keken et al. [van Keken et al., 2002]. 
Many thermal models do not predict temperatures as high as $1300^{\circ} \mathrm{C}$ for the mantle wedge beneath the arc at any depth, and thus appear to be inconsistent with petrologic constraints. One caveat is that trajectories of melt migration beneath an arc might not be vertical. Porous flow might lead to melt migration vectors that ascend diagonally toward the wedge corner either due to pressure gradients in the mantle flow [Spiegelman and McKenzie, 1987; Phipps Morgan, 1987] or due to gravity driven porous flow beneath a sloping permeability barrier [Sparks and Parmentier, 1991]. Melt transport in fractures might follow a similar trajectory [e.g., Davies, 1999]. However, most thermal models predict a minimum depth of $\sim 90 \mathrm{~km}$ for the $1300^{\circ} \mathrm{C}$ isotherm in the wedge. Van Keken et al. [2002] predict $65 \mathrm{~km}$ beneath the Cascades and NE Japan. Thus, petrologic constraints are, indeed, inconsistent with previous thermal models of the mantle wedge.

One possible explanation for the disagreement between petrologic constraints and thermal models might be that temperatures of magmatic equilibration with mantle peridotite need not lie along a steadystate geotherm. In this case, the PT estimates from mantle/melt equilibration and from metamorphic closure conditions would not be representative of the pressure and temperature typical in the shallow mantle and lower crust most of the time. For example, melt in a transient magma chamber could equilibrate with wall rock that was heated to temperatures well above steady-state values at a given depth (Figure 2). Elkins-Tanton et al. [2001] noted that previous studies predict substantial partial melting of the lower crust if mantle temperatures at $36 \mathrm{~km}$ are as hot as $1290^{\circ} \mathrm{C}$ [Mareschal and Bergantz, 1990]. Because seismic data suggest that arc lower crust is mostly solid, Elkins-Tanton et al. suggested that relatively high, lower crustal temperatures must be localized and transient. However, models of lower crustal melting depend critically on composition; lower crust composed of refractory, plutonic rocks formed by partial crystallization of primitive magmas at high temperature could be entirely solid at the liquidus of mafic basalt.

Finally, many primitive arc magmas do not have low $\mathrm{H}_{2} \mathrm{O}$ contents, and some could have equilibrated with the mantle at temperatures lower than $1300^{\circ} \mathrm{C}$. Nonetheless, if current estimates of $\mathrm{H}_{2} \mathrm{O}$ contents in primitive arc basalts ( 2 to $4 \mathrm{wt} \%$, e.g., [Sisson and Layne, 1993]) are correct, the ubiquity of primitive basalts and basaltic andesites in arcs worldwide suggests that magmatic temperatures of $1200^{\circ} \mathrm{C}$ or more must be common (see results for the Aleutian arc in Kelemen et al., 2002, this volume). Together with seismic data (Section 3), which suggest that melt is present in much of the shallow mantle beneath arcs, this suggests that the shallow mantle must commonly be at $1200^{\circ} \mathrm{C}$ or more.

\section{2b. Metamorphic Closure Temperatures at the Base of arc Crust}

Two tectonically exposed arc sections, the Kohistan section in Pakistan [e.g., Tahirkheli et al., 1979] and the Talkeetna section in south central Alaska [e.g., DeBari and Coleman, 1989; Plafker et al., 1989; Burns, 1985], include exposures of the base of the crust and the uppermost mantle. In the Kohistan section, metamorphic assemblages in the lower crustal Chilas and Kamila complexes record 700 to $850^{\circ} \mathrm{C}$ at 0.5 to $0.8 \mathrm{GPa}$. Along the IndianAsian suture zone (the Main Mantle thrust), metaplutonic mineral temperatures record higher $\mathrm{P} / \mathrm{T}$. However, the higher pressure end of this spectrum may record partial subduction of and then exhumation during continental collision.

For the Talkeetna section, DeBari \& Coleman estimated metamorphic conditions during garnet formation in gabbros at the base of the crust at $\sim 1$ $\mathrm{GPa}, 825-900^{\circ} \mathrm{C}$ [DeBari and Coleman, 1989]. In Figure 3 and Table 1, we present seven new PT determinations for hornblende-bearing garnet gabbros and garnet gabbronorites from the Talkeetna section made with THERMOCALC v3.1 ([Holland and Powell, 1988], May 2001 database). Calculations made with TWQ v1.02 [Berman, 1991; Lieberman and Petrakakis, 1991; Berman, 1990; Berman, 1988] confirm these results. Ellipses shown in Figure 3 are $1 \sigma$ uncertainties determined by the intersection of multi-variant equilibria. The equilibria with steepest PT slopes (thermometers) are exclusively $\mathrm{Fe}-\mathrm{Mg}$ exchange among garnet, orthopyroxene, clinopyroxene, and amphibole, whereas reactions with gentle PT slopes (barometers) are generally net-transfer reactions involving garnet, pyroxene, amphibole, and plagioclase, plus quartz in quartz-bearing samples. Garnets show broad core-torim zoning toward higher $\mathrm{Fe} / \mathrm{Mg}$, whereas pyroxenes display only near-rim, steep decreases in $\mathrm{Fe} / \mathrm{Mg}$ and $\mathrm{Al}_{2} \mathrm{O}_{3}$; plagioclase crystals are unzoned. We interpret this to be the result of early cooling (during or after garnet growth), which produced garnet zoning and likely homogenization of pyroxene, followed by later, more-rapid cooling that produced the steep zoning in pyroxene rims. Because of the inferred pyroxene homogenization, temperatures calculated from mineral cores are minima. 
The mineral core compositions suggest that two garnet gabbronorites at the base of the arc section near Tonsina crystallized at $\sim 980-1025^{\circ} \mathrm{C}, 1.0-1.1$ $\mathrm{GPa}$, and three garnet gabbros exposed as mafic pods or thin garnet-bearing bands within garnet-absent, layered gabbros indicate conditions of $\sim 890-980^{\circ} \mathrm{C}$, $0.8-1.0 \mathrm{GPa}$. Two samples from higher in the arc section, in the Klanelneechina klippe, about $50 \mathrm{~km}$ SW of the Tonsina area, indicate significantly lower core temperatures and pressures of $\sim 665-690^{\circ} \mathrm{C}, 0.6$ GPa.

In addition to the data from exposed arc sections, DeBari et al. [1987] estimated temperatures of 980$1030^{\circ} \mathrm{C}$ in deformed, metaplutonic xenoliths from Adagdak volcano in the Aleutian arc. The xenoliths are presumed to be derived from the base of the arc crust, which is about $35 \mathrm{~km}$ thick [Holbrook et al., 1999].

The metamorphic temperatures described in the previous paragraphs are almost certainly closure temperatures, rather than peak temperatures; that is, the plutonic protoliths of the rocks crystallized at higher, igneous temperatures. Sisson \& Grove [1993] and Yang et al. [1996] developed methods for estimating the temperature, pressure and water content of crystallization for basaltic melts saturated in olivine, clinopyroxene and plagioclase. Using these methods, one can calculate that crystal fractionation of primitive lavas beneath the southern Oregon Cascades occurs at the base of the crust, at conditions of $1100-1300{ }^{\circ} \mathrm{C}$ and 0.8 to $1.0 \mathrm{GPa}$ [Elkins Tanton et al., 2001]. Similarly, DeBari \& Coleman [1989] estimated that gabbronorites at the base of the Talkeetna arc crust originally crystallized at temperatures of $1100^{\circ} \mathrm{C}$ or more, and then cooled to the metamorphic conditions at which garnet formed. Thus, it is likely that the metamorphic assemblages in these rocks equilibrated along an arc geotherm, at temperatures greater than or equal to the closure temperatures they now record.

As for the magma-mantle equilibration temperatures described in Section 2a, it is conceivable that all the PT estimates for metaplutonic rocks near the base of the crust in the Kohistan and Talkeetna arc sections are "contact metamorphic", reflecting high temperatures associated with transient melt lenses or magma chambers. In this latter view, they do not necessarily represent constraints on a steady-state arc geotherm. However, in the next section we argue that consistent observation of low seismic velocities in the uppermost mantle beneath arc crust indicates that melt is commonly present at Moho depths.

\section{SEISMIC CONSTRAINTS ON MELT DISTRIBUTION IN THE UPPERMOST MANTLE}

Teleseismic tomography reveals that a -4 to $-6 \%$ $\mathrm{P}$-wave velocity anomaly and a -6 to $-10 \%$ S-wave velocity anomaly in the uppermost mantle underlies at least $50 \%$ of the Moho beneath the NE Japan arc over $\sim 500 \mathrm{~km}$ along strike [Zhao and Hasegawa, 1994; Zhao and Hasegawa, 1993; Zhao et al., 1992a; Zhao et al., 1992b]. This low velocity anomaly relative to a reference model with mantle $\mathrm{P}$ - and Swave velocities from 7.7 and $4.34 \mathrm{~km} / \mathrm{s}$ at $40 \mathrm{~km}$ depth to 7.9 and $4.45 \mathrm{~km} / \mathrm{s}$ at $90 \mathrm{~km}$ - extends from the base of the crust at $35 \mathrm{~km}$ to $\sim 50 \mathrm{~km}$ depth beneath the arc, and has a width of $\sim 50-75 \mathrm{~km}$ in sections perpendicular to the arc. Similar results have been obtained for the Tonga arc [Zhao et al., 1997]. While the results for both NE Japan and Tonga could be artifacts due to undetected seismic anisotropy, preliminary analysis suggests that the actual effect of anisotropy in these areas is small [Zhao, pers. comm. 2000]. Similar seismic anomalies in the MELT region beneath the East Pacific Rise have been taken to indicate the presence of melt in mantle peridotite at temperatures greater than $1300^{\circ} \mathrm{C}$ [Forsyth et al., 1998a; Forsyth et al., 1998b]. A similar inference may be warranted for the mantle beneath NE Japan, though temperatures could be lower because $\mathrm{H}_{2} \mathrm{O}$ will stabilize mantle melts at lower temperatures. Making another analogy to mid-ocean ridges, we think melt fractions are high near the base of arc crust due to the presence of a "permeability barrier", formed by crystallization of cooling melt in intergranular porosity [e.g., Kelemen and Aharonov, 1998; Sparks and Parmentier, 1991]. The regionally extensive nature of the seismic anomaly suggests that the presence of melt is a steady-state feature of the uppermost mantle beneath the NE Japan and Tonga arcs.

Tamura et al. [Tamura et al., 2001] have proposed that groups of volcanoes in NE Japan are underlain by low velocity anomalies as described in the preceding paragraph, with an along strike extent of 50-100 km, separated by regions with higher seismic velocity in the uppermost mantle. They suggest that this is a result of three-dimensional mantle convection in the wedge, perhaps due to transient diapirs. We agree that advective heat transport via three-dimensional mantle convection might give rise to substantial lateral temperature variation along strike on a scale of $50-100 \mathrm{~km}$. However, this provides little insight into whether melt is present along much of the Moho at steady-state, or not. 
Obviously, subduction zones and arcs evolve with time, so that the idea of a "steady state" is an oversimplification. Also, seismic data can only tell us about the present, so that one could ask if the regionally extensive thermal anomalies in the shallow mantle, observed beneath the NE Japan and Tonga arcs, are simply snapshots of an ephemeral though widespread phenomenon. Perhaps, most of the time, most of the shallow mantle does not have anomalously slow seismic velocities. However, we consider this alternative to be unlikely, and seek thermal models that are consistent with petrological PT constraints at steady-state.

\section{RAPID ADVECTION IN THE MANTLE WEDGE}

Data in the preceding sections, taken together, suggest that temperatures beneath arcs are higher than $1000^{\circ} \mathrm{C}$ at $\sim 30 \mathrm{~km}$, and approach $1300^{\circ} \mathrm{C}$ or more at $45 \mathrm{~km}$. This is inconsistent with all published thermal models for arcs, as seen in Figure 1. One potential resolution of this discrepancy is to consider the effects of rapid advection of mantle peridotite in the shallowest part of the mantle wedge. In this section, we present results of numerical models that incorporate temperature-dependent viscosity to model solid-state flow by thermally activated creep, with a range of activation energies and "asthenospheric" viscosities.

\section{4a. Experimentally Constrained Mantle Viscosities}

As discussed by Hirth \& Kohlstedt [Hirth and Kohlstedt, 2002, this volume] viscosities in the range of $10^{17}$ to $10^{21} \mathrm{~Pa} \mathrm{~s}$ are within the range experimentally measured for olivine at upper mantle temperatures and pressures. Viscosities in the low end of this range probably require both dissolved hydrogen [Mei and Kohlstedt, 2000; Hirth and Kohlstedt, 1996; Kohlstedt et al., 1996], as might be expected in the relatively $\mathrm{H}_{2} \mathrm{O}$-rich mantle above a subduction zone, and melt fractions greater than $\sim 3$ $\%$ [Kelemen et al., 1997; Hirth and Kohlstedt, 1995a; Hirth and Kohlstedt, 1995b]. In particular, a combination of partial melt and dissolved $\mathrm{H}_{2} \mathrm{O}$ could produce mantle viscosities less than $10^{18} \mathrm{~Pa} \mathrm{~s}$ at pressures of 1 to $6 \mathrm{GPa}$. However, to date no thermal model of a subduction zone has incorporated such low viscosities.

\section{4b. Activation Energy in Solid State Creep of the Mantle}

The temperature dependence of viscosity during diffusion creep of olivine aggregates can be written

$$
\mu / \mu_{\infty}=\exp \left[Q /\left(R T_{\infty}\right) *\left(\mathrm{~T}_{\infty} / \mathrm{T}-1\right)\right]
$$

with an experimentally determined activation energy Q of $315 \mathrm{~kJ} / \mathrm{mol}$ [Hirth and Kohlstedt, 1995b], equivalent to a value of $Q /\left(R T_{\infty}\right)$ of $\sim 24$ to 26 at asthenospheric temperatures. $\mu_{\infty}$ and $T_{\infty}$ are the asthenospheric viscosity and temperature, respectively. Stress-dependence might lower the "effective" activation energy [Christensen, 1984]. An activation energy of $250 \mathrm{~kJ} / \mathrm{mol}$, yields $\mathrm{Q} /(\mathrm{RT} \infty) \sim 18$ to 21 , though higher values of $\mathrm{Q}$ might be appropriate for cases involving dislocation creep in which stress is maintained at a high value. In our modeling, we have used values of $Q /\left(R T_{\infty}\right)$ ranging from 0 to 40 . Most of the models presented by Kincaid \& Sacks [Kincaid and Sacks, 1997] used $Q /\left(R T_{\infty}\right)$ of 30.

\section{4c. Description of Modeling Technique}

Models of solid state flow and temperature in the mantle wedge above a subducting slab are formulated using a hybrid finite-element/finite difference method. Viscous flow with large viscosity variations is calculated using a standard penalty function finite element formulation with linear interpolation functions on quadrilateral elements [cf. Reddy, 1993]. The resulting algebraic equations are solved by a Gaussian elimination method, which is stable and reasonably accurate for the large viscosity variations expected with a strongly temperaturedependent viscosity. The conservation equation describing the advection and diffusion of heat is solved using a finite difference or finite volume approximation on a non-uniform rectangular grid with volumes centered on finite element node points. A second order accurate solution is obtained using centered spatial differences for the diffusion terms and a diffusion-corrected upwind method [Smolarkiewicz, 1983] for the advection terms. We think that this advection method is preferable to the first order accurate streamline upwind method usually employed in finite element discretizations of the temperature field which can produce significant numerical diffusion. Time-dependent steady-state solutions are obtained by a simple forward time step of the advection-diffusion equation with a stability limited time step. These solutions represent deviations from an adiabatic temperature gradient which can be simply added to the solutions. We do 
not account for the heat of melting or mineral reactions or the contribution of melt migration to heat transport.

The models that we present in this paper use a uniformly spaced mesh in a $900 \mathrm{~km}$ wide by $600 \mathrm{~km}$ deep domain (see Figure 4). In the horizontal direction nodes are spaced every $\sim 10 \mathrm{~km}$, and in the vertical direction every $\sim 7 \mathrm{~km}$. This is comparable to the resolution in the recent models of [Kincaid and Sacks, 1997]. The top of the domain is a no-slip boundary on which the temperature is set to zero. On the bottom, we have experimented with both a freeslip, flow-through boundary on which the viscous stresses vanish and a free-slip, closed boundary on which the normal velocity component vanishes. The results presented here use the flow-through boundary, but this choice makes little difference within about $300 \mathrm{~km}$ of the wedge corner. The right vertical boundary is a flow-through boundary. In areas of inward flow, temperature is set to the prescribed mantle potential temperature, $1350^{\circ} \mathrm{C}$ for the cases presented here. This corresponds physically to placing a back-arc spreading center at this boundary. The choice of a mantle potential temperature of $1350^{\circ} \mathrm{C}$ is by analogy to mid-ocean ridges. Experimental and theoretical constraints on melt productivity during decompression melting have been combined with geochemical studies of the trace element contents of mantle peridotites and mid-ocean ridge basalts (MORB), and with seismic determinations of oceanic crustal thickness, to yield estimates ranging from 1280 to $1400^{\circ} \mathrm{C}$ for potential temperature in the upwelling mantle beneath ridges [e.g., Braun et al., 2000; Langmuir et al., 1992; White et al., 1992; McKenzie and Bickle, 1988; Allègre et al., 1973].

Velocities along the left vertical boundary and in a triangular region in the lower left corner of the domain are prescribed to be the subducting plate velocity. The temperature distribution on this boundary is an error function that would result from vertical conductive cooling of the upper mantle. We examine mantle thermal ages of 25, 50, 80 and 100 Myr, and convergence rates of 20, 40, 60, 80, and $100 \mathrm{~km} / \mathrm{Myr}$ with a slab dip of $45^{\circ}$. This is a reasonable value based on the wide range of slab dips that are observed [cf. Jarrard, 1986].

A very viscous region develops near the cold top boundary. In this region significant flow should not occur by thermally activated creep. A maximum viscosity that is a factor of $10^{4}$ greater than that of the deeper mantle was prescribed. To avoid concerns that this very viscous material would "stick to" the plate and be carried downward with it, a layer of very weak nodes was introduced along the top of the slab at depths shallower than $50 \mathrm{~km}$ (see Figure 4). Kincaid \& Sacks [1997] also used this method of introducing a "fault" consisting of a dipping layer of weak nodes. Shear heating along the fault would increase temperatures in the subducting plate and mantle wedge compared to our model results. In contrast to the models of [van Keken et al., 2002], we introduce no heating on the fault. However, later in this paper we estimate the temperature increase that could be associated with this effect.

We consider $\mu_{\infty}$ values ranging from $10^{17}$ to $10^{21}$ $\mathrm{Pa}-\mathrm{s}$. Each case is run to a time-dependent steady state in which the temperature and velocity fields are relatively constant and the overall thickness of the thermal boundary layer no longer changes (Figure 5). At the lower values of $\mu_{\infty}$ a time-independent steady state is not attained because the cold, dense thermal boundary layer beneath the overriding plate "drips" into the mantle wedge (see Figures 4 and 5). This behavior has only a small effect on temperatures within a few hundred $\mathrm{km}$ of the wedge corner. The time to steady state in the models is $\sim 100 \mathrm{Myr}$. However, temperatures in the wedge corner approach a steady state in $~ 10 \mathrm{Myr}$ (Figure 5).

\section{4d. Model Results}

As also seen in earlier thermal models incorporating temperature-dependent viscosity [Kincaid and Sacks, 1997; Furukawa, 1993a; Furukawa, 1993b], cooling of the top and subduction-side of the mantle wedge forms an increasing volume of high viscosity material that is incorporated in thermal boundary layers. Paradoxically, this leads to thinning of the thermal boundary layers, especially near the wedge corner, because of the enhanced entrainment of cold, viscous mantle with the subducting plate. This advective thinning of the thermal boundary layer in the wedge drives rapid return flow of hot mantle into the wedge corner. Also, in cases with low $\mu_{\infty}$, buoyancy forces drive convection (a cold density current running down the top of the slab and "drips" from the bottom of the overriding plate), so that mantle convection velocities may actually exceed the subduction velocity.

Perhaps the most obvious manifestation of this effect is that flow of hot material into the wedge follows a diagonal upward trajectory toward the wedge corner, accelerating at shallow depths, as seen in previous studies. This contrasts with isoviscous models, in which return flow into the wedge is nearly horizontal. We illustrate this difference in Figure 6. 
Panel A, for isoviscous corner flow with $\mu_{\infty}=10^{21} \mathrm{~Pa}$ $\mathrm{s}$, has thick thermal boundary layers at the top and along the subduction zone side of the mantle wedge, and horizontal return flow of the upper mantle into the wedge corner. Panels $\mathrm{B}$ and $\mathrm{C}$ have $Q /\left(R T_{\infty}\right)=$ 20. Though the models in $\mathrm{B}$ and $\mathrm{C}$ differ by three orders of magnitude in asthenospheric viscosity $\left(\mu_{\infty}=\right.$ $10^{21} \mathrm{~Pa} \mathrm{~s}$ in $\mathrm{B}, \mu_{\infty}=10^{18} \mathrm{~Pa} \mathrm{~s}$ in $\mathrm{C}$ ), temperatures in the two models are very similar, and both very different from $\mathrm{A}$, with thinner thermal boundary layers and diagonally ascending return flow into the wedge corner. The upward flow induced by temperature dependent viscosity could lead to decompression melting of the mantle.

Our results for models with temperature-dependent viscosity in Figure 6 show significant thinning of the thermal boundary layer. The recent models of van Keken et al. [2002] (see their Figure 3) and Conder et al. [2002] also show this thinning, although in their models the amount of thinning appears to be limited by the presence of a rigid "lithospheric" layer of prescribed thickness. [Furukawa, 1993a; Furukawa, 1993b] also prescribed a fixed lithospheric thickness. In contrast, we have assumed that the use of a temperature-dependent viscosity should be sufficient to allow the "lithosphere" to find its own thickness.

The results of Kincaid and Sacks [1997] do not show the thinning we observe in our models. One reason for this difference could be that our models are run to "steady state", whereas Kincaid \& Sacks concentrated on time-dependent results soon after the initiation of subduction, within the first 2 to $4 \mathrm{Myr}$ for "fast" subduction at $100 \mathrm{~km} / \mathrm{Myr}$, and within the first 20 to $40 \mathrm{Myr}$ for "slow" subduction at 13 $\mathrm{km} / \mathrm{Myr}$. As can be seen in our Figure 4, thinning of the top thermal boundary layer in the wedge corner takes time; it is not present at the initial stages of our models (e.g., after 2.6 Myr of subduction at 60 $\mathrm{km} / \mathrm{Myr}$ in panel B) but is fully developed at "steady state" (e.g., after $15 \mathrm{Myr}$ of subduction at $60 \mathrm{~km} / \mathrm{Myr}$ in panel C).

In comparing our results to previous work, we should also re-emphasize that our models extended to much lower asthenospheric viscosities $\left(\mu_{\infty}\right.$ as low as $10^{17} \mathrm{~Pa} \mathrm{~s}$, compared to $\mu_{\infty} \geq 10^{20} \mathrm{~Pa} \mathrm{~s}$ in all previous models). This does not make a first-order difference in our models (compare Figure 6B with $\mu_{\infty}=10^{21} \mathrm{~Pa}$ s and $6 \mathrm{C}$ with $\mu_{\infty}=10^{18} \mathrm{~Pa} \mathrm{~s}$ ), but models with $\mu_{\infty}$ of $10^{18}$ and $10^{17} \mathrm{~Pa}$ s do show additional thinning of the 'lithosphere' due to the dripping of relatively cold material from the base of the thermal boundary layer (see Figures 4C and 5).

Figure 7 illustrates our model results in terms of temperature variation at steady state, with depth along vertical sections where the top of the overriding plate is 100 and $150 \mathrm{~km}$ above the subducting plate. We emphasize two major features of these results. First, most of the models with temperaturedependent viscosity provide a close fit to the petrological constraints on pressure and temperature in the lower crust and upper mantle beneath arcs. Second, all models with $\mu_{\infty}$ of $10^{17}, 10^{18}$ and $10^{21}$, together with $Q /\left(R T_{\infty}\right)$ of 10 and 20 , predict temperatures near the top of the subducting plate that are higher than experimentally constrained fluidsaturated solidii for metasediment and metabasalt at 100 to $150 \mathrm{~km}$ depth in the subduction zone. Taken at face value, comparison of model results to experimental solidii suggests that a variety of conditions can cause fluid-saturated melting of subducted sediment, while melting of subducted basalt might be rare. However, since metasediment and metabasalt in eclogite facies both have the same mineral assemblage (garnet, omphacitic clinopyroxene, coesite and phengite), both probably have approximately the same solidus, within the bounds of variation due to bulk composition in both rock types [Schmidt, pers. comm., 2000].

Shear heating in the fault zone between the subducting and overriding plates will increase temperatures along the top of the slab. Based on heat flow in the forearc [Peacock and Wang, 1999], van Keken, et al. [2002] adopt a shear heating rate of about $30 \mathrm{~mW} / \mathrm{m} 2$ along this fault for NE Japan. A simple estimate of the temperature increase along the fault can be obtained from the solution for transient heat conduction into a halfspace with a prescribed heat flux at the halfspace surface [Carslaw and Jaeger, 1959, p. 75 , equation (8)] corresponding to the fault. The temperature increase on the fault is

$$
\Delta T=\frac{\sigma V}{\rho c_{p}} \sqrt{\frac{t}{\pi \kappa}}
$$

where time in this, $t$, corresponds to distance along the fault divided by the slip velocity $V$, and $\sigma$ is the effective shear stress on the fault. For a plate thickness of $50 \mathrm{~km}$ with a $45^{\circ}$ dipping fault, $V=60$ $\mathrm{km} / \mathrm{Myr}$, and a fault heating rate $\sigma V=30 \mathrm{~mW} / \mathrm{m}^{2}$, $\Delta T=40^{\circ} \mathrm{C}$. Adding this temperature to our calculated temperature along the top of the slab gives the dashed curve shown in Figure 7B. This increase in temperature enhances the possibility of wet basalt melting.

Figure 8 illustrates our results in terms of predicted heat flow, compared to heat flow data from northeast Japan (compiled by [Furukawa, 1993a]) 
and from southwestern Oregon [Blackwell et al., 1982]. It is clear that the isoviscous model fails to account for heat flow in arcs, as previously noted by Furukawa, for example. Model heat flow is calculated using thermal conductivity of $3.0 \mathrm{~W} /(\mathrm{m}$ $\mathrm{K})$. Previous models have not been able to explain heat flow in excess of $100 \mathrm{~mW} / \mathrm{m}^{2}$, and the interpretation of such high values in terms of a "steady state" geotherm has been controversial. Our models provide a good fit to the high heat flow in arcs and the large heat flow gradient toward the forearc. An artifact of specifying a subducting plate with constant dip is that the heat flow maximum in our models with temperature-dependent viscosity appears to occur very close to the "trench". Models with a more realistic plate geometry with low dip at shallow depths, steepening below $\sim 50 \mathrm{~km}$, should produce a more realistic distance between the trench and the heat flow maximum.

In presenting these results, we do not mean to suggest that we "know" that the mantle wedge in all subduction zones has an asthenospheric viscosity between $10^{17}$ and $10^{21} \mathrm{~Pa} \mathrm{~s}$, with $Q /\left(R T_{\infty}\right)$ of 20 . As noted in the previous paragraph, we have not yet explored the effects of varying slab dip. Our models do not incorporate shear heating and stress-dependent viscosity (unlike the models of [van Keken et al., 2002], nor have we incorporated pressure-dependent viscosity. Further consideration could also be given to specifying a suitable fault geometry in the upper $50 \mathrm{~km}$ of the subduction zone. Perhaps most importantly, our models are two-dimensional, whereas there is abundant evidence that mantle flow in the wedge is three-dimensional.

However, our results clearly show that thermal models for subduction zones can be consistent with the petrological estimates for temperature at the base of the crust and in the upper mantle beneath arcs. Furthermore, some of these thermal models, using widely accepted values for viscosity and thermal activation energy, can explain partial melting of subducted sediment and basalt in subduction zones. This is the case despite the fact that our models do not incorporate shear heating along the "fault zone", which would yield higher subduction zone temperatures. We obtain these results for subduction of $50 \mathrm{Myr}$ old oceanic crust at $60 \mathrm{~km} / \mathrm{Myr}$, and even for $80 \mathrm{Myr}$ old crust subducting at $80 \mathrm{~km} / \mathrm{Myr}$, suggesting that melting of subducted material is not restricted to slow subduction of young oceanic crust.

\section{GRAVITY AND TOPOGRAPHY IN OCEANIC ARCS}

Viscous coupling between the mantle wedge and the subducting plate is assumed in purely platedriven, isoviscous models for arcs, and predicted in dynamical models for arcs with mantle viscosities $\geq$ $10^{20} \mathrm{~Pa} \mathrm{~s}$. However, coupling between the mantle wedge and the dense, subducting plate should produce a Bouguer gravity low over arcs [Zhong and Gurnis, 1992], whereas no such lows are observed. This discrepancy can be resolved if the mantle wedge has a lower viscosity, permitting mechanical decoupling between the wedge and the subducting plate [Billen and Gurnis, 2001]. Billen \& Gurnis estimate that a region in the wedge extending from 20 to $\geq 100 \mathrm{~km}$ depth, with a viscosity $\geq 10$ times weaker than the ambient upper mantle viscosity ( $10^{20} \mathrm{~Pa} \mathrm{~s}$ in their parameterization), yields the best fit to topographic and gravity data for the TongaKermadec and Aleutian arcs. Lowering the viscosity to values 100 to 1000 times weaker than the ambient upper mantle viscosity does not significantly affect their results. Thus, the gravity and topography data are consistent with the low viscosities in the wedge corner produced by models with temperaturedependent viscosity (e.g., Figures 6B and 6C), and inconsistent with the results for an isoviscous wedge with a viscosity of $10^{21} \mathrm{~Pa}$ s in Figure 6A.

In detail, the results of Billen \& Gurnis imply that the low viscosity part of the mantle wedge should be restricted to shallow depths, within $\sim 200 \mathrm{~km}$ of the surface. This suggests that pressure dependence of mantle viscosity may be important in explaining gravity and topography in arcs. This is an important area for future investigation.

\section{CAVEATS}

\section{6a. Compositional Convection in the Wedge?}

The wedge flow discussed in this paper is driven only by viscous entrainment and thermal buoyancy, and not from the buoyancy of retained melt and/or reduced $\mathrm{Fe} / \mathrm{Mg}$ in the residues of melting. Such compositional convection has been predicted in numerical studies of subduction zone magmatism [Iwamori, 1997; Davies and Stevenson, 1992]. Buoyancy forces arising from the presence of low density melt within its mantle source are very sensitive to assumptions regarding the permeability of intergranular melt networks in mantle peridotite. High permeabilities will yield efficient melt transport and little melt buoyancy. Geophysical and geochemical studies, even at very fast-spreading midocean ridges suggest that very little melt is retained in the mantle [e.g., Forsyth et al., 1998a]. As a result, 
we suspect that permeabilities are high within partially molten mantle peridotite, at least within those regions with an adiabatic or hotter geothermal gradient, in which ascending melt can dissolve minerals and increase permeability downstream [e.g., Kelemen et al., 1995]. This implies that convection driven by buoyancy due to the presence of melt within partially molten aggregates in the mantle wedge is unlikely.

A variety of evidence favor the hypothesis that adiabatic decompression of the mantle is important in the genesis of some arc lavas [e.g., Elkins Tanton et al., 2001; Sisson and Bronto, 1998; Plank and Langmuir, 1988; and Langmuir \& Spiegelman, pers. comm. 2002], and this is sometimes taken as evidence for vertical diapirism due to melt buoyancy [e.g., Tatsumi et al., 1983]. However, models for arcs that incorporate temperature-dependent viscosity [e.g., van Keken et al., 2002; Furukawa, 1993a; Furukawa, 1993b] predict an upward component of mantle flow behind and beneath the arc, in the absence of melt-driven convection. Thus, adiabatic decompression melting in arcs does not require vertical diapirism due to melt buoyancy.

\section{6b. Analytical Corner Flow Models, arc Position, and arc Magma Composition}

As mentioned in Section 1, analytical, isoviscous corner flow calculations have long been a popular and simple way to estimate flow and temperature in the mantle wedge above subduction zones. The results of these physically simple calculations are strikingly similar to those of more complicated numerical calculations, which accounts for the lasting appeal of the analytical approach. In this paper, however, we argue that analytical, isoviscous corner flow calculations, together with their more complicated numerical siblings, systematically fail to predict the first-order temperature distribution in the shallow mantle and lowermost crust beneath arcs.

Recent work has demonstrated that simple corner flow solutions provide insight into subduction-related magmatism. England [England, 2001] found that analytical estimates of temperature in the mantle wedge are correlated with the depth to the subducting plate beneath arcs and with the major element composition of arc basalts. A similar correlation is expected in models like ours that incorporate realistic mantle viscosity variation. The wedge thermal structure, while necessarily different than in isoviscous models, is expected to have a qualitatively similar dependence on parameters such as age of subducting plate and subduction rate. From correlations like those observed, we would infer that the temperature distribution in the mantle wedge is, indeed, a strong control on the location of arcs and the composition of lavas. This should be a fertile area for future research.

\section{CONCLUSION}

In sections 2 and 3, we show that published thermal models fail to account for a variety of important constraints on the temperature and viscosity structure of the mantle wedge beneath arcs. A clear alternative is that thermal boundary layers at the base of arc crust and along the subduction zone are thinner than has been assumed or calculated in models thus far. This would satisfy constraints from petrology on the temperature in the wedge at the base of arc crust and at $\sim 45 \mathrm{~km}$ depth within the mantle wedge. Also, temperatures in subducted metabasalt and metasediment could rise above the fluidsaturated solidus, permitting partial melting if fluid is available.

In section 4, we show that thermal models incorporating temperature-dependent viscosity, using widely accepted values for activation energy and asthenospheric viscosity, produce a thin thermal boundary layer beneath the arc, and an overall thermal structure that is consistent with petrological constraints on temperature in arc lower crust and shallow mantle. Some of these models are hot enough to allow for partial melting of subducted sediment and/or basalt, even though we have not incorporated the effect of shear heating. We obtain these results for subduction of $50 \mathrm{Myr}$ old oceanic crust at $60 \mathrm{~km} / \mathrm{Myr}$, and even for faster subduction of older crust, suggesting that melting of subducted crust may not be restricted to slow subduction of very young oceanic crust.

Acknowledgements. We are very grateful to Greg Hirth, Magali Billen and Jack Whitehead for extensive advice on mantle rheology, dynamical modeling, and arc magmatism. Deiping Zhao and Max Schmidt shared unpublished results and thoughts on wedge temperature and partial melting of subducted sediment and basalt. Peter van Keken generously provided a preprint of a paper using a nonlinear rheology to model wedge convection. We thank Karen Hanghøj for help in compiling the results from thermal models and arc thermobarometry in Figure 1. Sue DeBari, Laurel Burns, and many others guided us in field work in the lower crustal exposures of the Talkeetna arc section. Kelemen, Mehl and Hacker were supported by 
NSF EAR-9910899. Kelemen was also supported in part by NSF EAR-0087706 and EAR-9814632.

\section{REFERENCES}

Allègre, C.J., R. Montigny, and Y. Bottinga, Cortège ophiolitique et cortège océanique, géochimie comparée et mode de genèse, Bull. Soc. géol. France, 15, 461-477, 1973.

Anczkiewicz, R., and D. Vance, Isotopic constraints on the evolution of metamorphic conditions in the Jijal-Patan complex and the Kamila Belt of the Kohistan arc, Pakistan Himalaya, Geol. Soc. Spec. Pub., 170, 321-331, 2000.

Bartels, K.S., R.J. Kinzler, and T.L. Grove, High pressure phase relations of primitive high-alumina basalts from Medicine Lake Volcano, Northern California, Contrib. Mineral. Petrol., 108, 253-270, 1991.

Berman, R.G., Internally-consistent thermodynamic data for stoichiometric minerals in the system Na2O-K2O$\mathrm{CaO}-\mathrm{MgO}-\mathrm{FeO}-\mathrm{Fe} 2 \mathrm{O} 3-\mathrm{Al} 2 \mathrm{O} 3-\mathrm{SiO} 2-\mathrm{TiO} 2-\mathrm{H} 2 \mathrm{O}-\mathrm{CO} 2, \mathrm{~J}$. Petrol., 29, 445-522, 1988.

Berman, R.G., Mixing properties of Ca-Mg-Fe-Mn garnets, Am. Min., 75, 328-344, 1990.

Berman, R.G., Thermobarometry using multiequilibrium calculations: A new technique with petrologic applications, Can. Min., 29, 833-855, 1991.

Billen, M.I., and M. Gurnis, A low viscosity wedge in subduction zones, Earth Planet. Sci. Lett., 193, 227-236, 2001.

Blackwell, D.D., R.G. Bowen, D.A. Hull, J. Riccio, and J.L. Steele, Heat flow, arc volcanism, and subduction in northern Oregon, J. Geophys. Res., 87, 8735-8754, 1982.

Braun, M.G., G. Hirth, and E.M. Parmentier, The effects of deep damp melting on mantle flow and melt generation beneath mid-ocean ridges, Earth Planet. Sci. Lett., 176, 339-356, 2000.

Brenan, J.M., H.F. Shaw, and R.J. Ryerson, Experimental evidence for the origin of lead enrichment in convergent margin magmas, Nature, 378, 54-56, 1995a.

Brenan, J.M., H.F. Shaw, R.J. Ryerson, and D.L. Phinney, Mineral - aqueous fluid partitioning of trace elements at $900^{\circ} \mathrm{C}$ and $2.0 \mathrm{GPa}$ : Constraints on trace element chemistry of mantle and deep crustal fluids, Geochim. Cosmochim. Acta, 59, 3331-3350, 1995 b.

Burns, L.E., The Border Ranges ultramafic and mafic complex, south-central Alaska: Cumulate fractionates of island-arc volcanics, Can. J. Earth Sci., 22, 1020-1038, 1985.

Carslaw, H.S., and J.C. Jaeger, Conduction of Heat in Solids, Oxford University Press, 510p., 1959.

Christensen, U., Convection with pressure- and temperature-dependent non-Newtonian rheology, Geophys. J. R. Astron. Soc., 77, 343-384, 1984.

Class, C., D.L. Miller, S.L. Goldstein, and C.H. Langmuir, Distinguishing melt and fluid components in Umnak Volcanics, Aleutian Arc, Geochemistry, Geophysics, Geosystems (G-cubed), 1, 2000.
Conder, J.A., D.A. Weins, and J. Morris, On the decompression melting structure at volcanic arcs and back-arc spreading centers, Geophys. Res. Lett., in press, 2002.

Davies, J.H., The role of hydraulic fractures and intermediate-depth earthquakes in generating subduction-zone magmatism, Nature, 398, 142-145, 1999.

Davies, J.H., and D.J. Stevenson, Physical model of source region of subduction zone volcanics, J. Geophys. Res., 97, 2037-2070, 1992.

DeBari, S., S.M. Kay, and R.W. Kay, Ultramafic xenoliths from Adagdak volcano, Adak, Aleutian Islands, Alaska: deformed igneous cumulates from the Moho of an island arc, J. Geol., 95, 329-341, 1987.

DeBari, S.M., and R.G. Coleman, Examination of the deep levels of an island arc: Evidence from the Tonsina ultramafic-mafic assemblage, Tonsina, Alaska, $J$. Geophys. Res., 94 (B4), 4373-4391, 1989.

Defant, M.J., and M.S. Drummond, Derivation of some modern arc magmas by melting of young subducted lithosphere, Nature, 347, 662-665, 1990.

Defant, M.J., and P. Kepezhinskas, Evidence suggests slab melting in arc magmas, EOS, 82, 65-69, 2001.

Draper, D.S., and A.D. Johnston, Anhydrous P-T phase relations of an Aleutian high-MgO basalt: An investigation of the role of olivine-liquid reaction in the generation of arc high-alumina basalts, Contrib. Mineral. Petrol., 112, 501-519, 1992.

Drummond, M.S., and M.J. Defant, A model for trondjhemite-tonalite-dacite genesis and crustal growth via slab melting, J. Geophys. Res., 95, 21,503-21,521, 1990.

Elkins Tanton, L.T., G. T. L, and J. Donnelly-Nolan, Hot shallow mantle melting under the Cascades volcanic arc, Geology, submitted, 2001.

Elliott, T., T. Plank, A. Zindler, W. White, and B. Bourdon, Element transport from slab to volcanic front at the Mariana Arc, J. Geophys. Res., 102, 14,991-15,019, 1997.

England, P.C., Abstract T22D-11, Why are the arc volcanoes where they are?, EOS, 82, F1156, 2001.

Forsyth, D.W., D.S. Scheirer, S.C. Webb, L.M. Dorman, J.A. Orcutt, A.J. Harding, D.K. Blackman, J. Phipps Morgan, R.S. Detrick, Y. Shen, C.J. Wolfe, J.P. Canales, D.R. Toomey, A.F. Sheehan, S.C. Solomon, and W.S.D. Wilcock, Imaging the deep seismic structure beneath a mid-ocean ridge; the MELT experiment, Science, 280 (5367), 1215-1218, 1998a.

Forsyth, D.W., S.C. Webb, L.M. Dorman, and Y. Shen, Phase velocities of Rayleigh waves in the MELT experiment on the East Pacific Rise, Science, 280 (5367), 1235-1238, 1998b.

Furukawa, Y., Depth of the decoupling plate interface and thermal structure under arcs, J. Geophys. Res., 98, 20,005-20,013, 1993a. 
Furukawa, Y., Magmatic processes under arcs and formation of the volcanic front, J. Geophys. Res., 98, 8309-8319, 1993b.

Furukawa, Y., and Y. Tatsumi, Melting of a subducting slab and production of high- $\mathrm{Mg}$ andesite magmas: Unusual magmatism in SW Japan at 13 approximately 15 Ma, Geophys. Res. Lett., 26 (15), 2271-2274, 1999.

Gough, S.J., M.P. Searle, D.J. Waters, and M.A. Khan, Igneous crystallization, high pressure metamorphism, and subsequent tectonic exhumation of the Jijal and Kamila complexes, Kohistan, Abstracts: 16th HimalayaKarakorum-Tibet Workshop, Austria, in J. Asian Earth Sciences, 19, 23-24, 2001.

Grove, T.L., S.W. Parman, S.A. Bowring, R.C. Price, and M.B. Baker, The role of $\mathrm{H} 2 \mathrm{O}$-rich fluids in the generation of primitive basaltic andesites and andesites from the Mt. Shasta region, N. California, Contrib. Mineral. Petrol., in press, 2001.

Hawkesworth, C.J., S.P. Turner, F. McDermott, D.W. Peate, and P. van Calsteren, U-Th isotopes in arc magmas: Implications for element transfer from the subducted crust, Science, 276, 551-555, 1997.

Hirth, G., and D. Kohlstedt, Rheology of the mantle wedge, in AGU Monograph Series, edited by J. Eiler, pp. submitted, American Geophysical Union, Washington DC, 2002.

Hirth, G., and D.L. Kohlstedt, Experimental constraints on the dynamics of the partially molten upper mantle 2 . Deformation in the dislocation creep regime, J. Geophys. Res., 100, 15,441-15,449, 1995a.

Hirth, G., and D.L. Kohlstedt, Experimental constraints on the dynamics of the partially molten upper mantle: Deformation in the diffusion creep regime, J. Geophys. Res., 100, 1981-2001, 1995b.

Hirth, G., and D.L. Kohlstedt, Water in the oceanic upper mantle: Implications for rheology, melt extraction and the evolution of the lithosphere, Earth Planet. Sci. Lett., 144, 93-108, 1996.

Holbrook, S.W., D.Lizarralde, S.McGeary, N. Bangs, and J. Diebold, Structure and composition of the Aleutian island arc and implications for continental crustal growth, Geology, 27, 31-34, 1999.

Holland, T.J.B., and R. Powell, An internally consistent thermodynamic data set for phases of petrological interest, J. metamorphic Geol., 16, 309-343, 1988.

Iwamori, H., Heat sources and melting in subduction zones, J. Geophys. Res., 102, 14,803-14,820, 1997.

Jan, M.Q., Geochemistry of amphibolites from the southern part of the Kohistan arc, N. Pakistan, Min. Mag., 52, 147-159, 1988.

Jan, M.Q., and R.A. Howie, Ortho- and clinopyroxenes from the pyroxene granulites of Swat Kohistan, northern Pakistan, Min. Mag., 43, 715-726, 1980.

Jan, M.Q., and A. Karim, Coronas and high-P veins in metagabbros of the Kohistan island arc, northern Pakistan; Evidence for crustal thickening during cooling, J. metamorphic Geol., 13, 357-366, 1995.
Jarrard, R.D., Relations among subduction parameters, Rev. Geophys., 24, 217-284, 1986.

Johnson, M.C., and T. Plank, Dehydration and melting experiments constrain the fate of subducted sediments, Geochemistry, Geophysics, Geosystems (G-cubed), 1, 1999.

Kay, R.W., Aleutian magnesian andesites: Melts from subducted Pacific ocean crust, J. Volc. Geotherm. Res., 4, 117-132, 1978.

Kelemen, P.B., and E. Aharonov, Periodic formation of magma fractures and generation of layered gabbros in the lower crust beneath oceanic spreading ridges, in Faulting and Magmatism at Mid-Ocean Ridges, Geophysical Monograph 106, edited by W.R. Buck, P.T. Delaney, J.A. Karson, and Y. Lagabrielle, pp. 267-289, Am. Geophys. Union, Washington DC, 1998.

Kelemen, P.B., G. Hirth, N. Shimizu, M. Spiegelman, and H.J.B. Dick, A review of melt migration processes in the asthenospheric mantle beneath oceanic spreading centers, Phil. Trans. Roy. Soc. London, A355, 283-318, 1997.

Kelemen, P.B., N. Shimizu, and V.J.M. Salters, Extraction of mid-ocean-ridge basalt from the upwelling mantle by focused flow of melt in dunite channels, Nature, 375, 747-753, 1995.

Keppler, H., Constraints from partitioning experiments on the composition of subduction-zone fluids, Nature, 380, 237240, 1996.

Kincaid, C., and I.S. Sacks, Thermal and dynamical evolution of the upper mantle in subduction zones, $J$. Geophys. Res., 102, 12,295-12,315, 1997.

Kinzler, R.J., Melting of mantle peridotite at pressures approaching the spinel to garnet transition: Application to mid-ocean ridge basalt petrogenesis, J. Geophys. Res., 102, 853-874, 1997.

Kinzler, R.J., and T.L. Grove, Primary magmas of midocean ridge basalts 1 . Experiments and methods, $J$. Geophys. Res., 97, 6885-6906, 1992a.

Kinzler, R.J., and T.L. Grove, Primary magmas of midocean ridge basalts 2. Applications, J. Geophys. Res., 97, 6907-6926, 1992b.

Kinzler, R.J., and T.L. Grove, Corrections and further discussion of the primary magmas of mid-ocean ridge basalts, 1 and 2, Journal of Geophysical Research, 98, 22,339-22,347, 1993.

Kohlstedt, D.L., H. Keppler, and D.C. Rubie, Solubility of water in alpha, beta, and gamma phases of (Mg,Fe)2SiO4, Contrib. Mineral. Petrol., 123, 345-357, 1996.

Lambert, I., B., and P. Wyllie, J., Melting of gabbro (quartz eclogite) with excess water to 35 kilobars, with geological applications, J. Geol., 80, 693-708, 1972.

Langmuir, C.L., E.M. Klein, and T. Plank, Petrological systematics of mid-ocean ridge basalts: Constraints on melt generation beneath ocean ridges, in Mantle flow and melt generation at mid-ocean ridges, AGU Monograph 71, edited by J. Phipps Morgan, D.K. Blackman, and 
J.M. Sinton, pp. 183-280, American Geophysical Union, Washington DC, 1992.

Lieberman, J., and K. Petrakakis, TWEEQU thermobarometry: Analysis of uncertainties and applications to granulites from western Alaska and Austria, Can. Min., 29, 857-887, 1991.

Mareschal, J.-C., and G. Bergantz, Constraints on thermal models of the Basin and Range province, Tectonophysics, 174, 137-146, 1990.

McKenzie, D., and M.J. Bickle, The volume and composition of melt generated by extension of the lithosphere, J. Petrol., 29, 625-679, 1988.

Mei, S., and D.L. Kohlstedt, Influence of water on plastic deformation of olivine aggregates 2. Dislocation creep regime, J. Geophys. Res., 105, 21471-21481, 2000.

Molnar, P., and P. England, Temperatures, heat flux, and frictional stress near Major thrust taults, J. Geophys. Res., 95, 4833-4856, 1990.

Molnar, P., and P. England, Temperatures in zones of steady-state underthrusting of young oceanic lithosphere, Earth and Planetary Science Letters, 131, 57-70, 1995.

Nichols, G.T., P.J. Wyllie, and C.R. Stern, Subduction zone melting of pelagic sediments constrained by melting experiments, Nature, 371, 785-788, 1994.

Peacock, S.M., Fluid processes in subduction zones, Science, 248 (4953), 329-337, 1990a.

Peacock, S.M., Numerical simulation of metamorphic pressure-temperature-time paths and fluid production in subducting slabs, Tectonics, 9 (5), $1990 \mathrm{~b}$.

Peacock, S.M., Numerical simulation of subduction zone pressure-temperature-time paths: Constraints on fluid production and arc magmatism, in Phil. Trans. Roy. Soc. London A 335: The Behaviour and Influence of Fluids in Subduction Zones, edited by J. Tarney, K.T. Pickering, R.J. Knipe, and J.F. Dewey, pp. 341-353, London, United Kingdom, 1991.

Peacock, S.M., Thermal and petrologic structure of subduction zones, in Subduction Zones, Top to Bottom: Geophysical Monograph 96, edited by G.E. Bebout, D.W. Scholl, S.H. Kirby, and J.P. Platt, pp. 119-133, Am. Geophys. Union, Washington DC, 1996.

Peacock, S.M., Thermal structure and metamorphic evolution of subducting slabs, in $A G U$ Monograph series, in press, edited by J. Eiler, American Geophysical Union, Washington DC, 2002.

Peacock, S.M., and R.D. Hyndman, Hydrous minerals in the mantle wedge and the maximum depth of subduction thrust earthquakes, Geophys. Res. Lett., 26, 2517-2520, 1999.

Peacock, S.M., T. Rushmer, and A.B. Thompson, Partial melting of subducting oceanic crust, Earth Planet. Sci. Lett., 121, 227-244, 1994.

Peacock, S.M., and K. Wang, Seismic consequences of warm versus cool subduction zone metamorphism: Examples from northeast and southwest Japan, Science, 286, 937-939, 1999.

Pearce, J.A., S.R. van der Laan, R.J. Arculus, B.J. Murton, T. Ishii, D.W. Peate, and I.J. Parkinson, Boninite and harzburgite from Leg 125 (Bonin-Mariana Forearc): A case study of magmagenesis during the initial stages of subduction, Proc. ODP, Scientific Results, 125, 623-659, 1992.

Phipps Morgan, J., Melt migration beneath mid-ocean spreading centers, Geophys. Res. Lett., 14, 1238-1241, 1987.

Plafker, G., W.J. Nokleberg, and J.S. Lull, Bedrock geology and tectonic evolution of the Wrangellia, Peninsular, and Chugach terranes along the trans-Alaska crustal transect in the Chugach Mountains and Southern Copper River Basin, Alaska, J. Geophys. Res., 94 (B4), 4255-4295, 1989.

Plank, T., Geochemistry; the brine of the Earth, Nature, 380, 202-203, 1996.

Plank, T., and C.H. Langmuir, An evaulation of the global variations in the major element chemistry of arc basalts, Earth Planet. Sci. Lett., 90, 349-370, 1988.

Plank, T., and C.H. Langmuir, Tracing trace elements from sediment input to volcanic output at subduction zones, Nature, 362, 739-743, 1993.

Plank, T., and C.H. Langmuir, The chemical composition of subducting sediment and its consequences for the crust and mantle, Chem. Geol., 145, 325-394, 1998.

Ponko, S.C., and S.M. Peacock, Thermal modeling of the southern Alaska subduction zone: Insight into the petrology of the subducting slab and overlying mantle wedge, J. Geophys. Res., 100, 22,117-22,128, 1995.

Rapp, R.P., N. Shimizu, M.D. Norman, and G.S. Applegate, Reaction between slab-derived melts and peridotite in the mantle wedge: Experimental constraints at 3.8 GPa, Chem. Geol., 160, 335-356, 1999.

Reddy, J.N., An Introduction to the Finite Element Method, 684 pp., McGraw-Hill, New York, 1993.

Ringuette, L., J. Martignole, and B.F. Windley, Magmatic crystallization, isobaric cooling, and decompression of the garnet-bearing assemblages of the Jijal sequence (Kohistan terrane, western Himalayas), Geology, 27, 139-142, 1999.

Schmidt, M.W., and S. Poli, Experimentally based water budgets for dehydrating slabs and consequences for arc magma generation, Earth and Planetary Science Letters, 163 (1-4), 361-379, 1998.

Sisson, T.W., and S. Bronto, Evidence for pressure-release melting beneath magmatic arcs from basalt at Galunggung, Indonesia, Nature, 391, 883-836, 1998.

Sisson, T.W., and T.L. Grove, Temperatures and $\mathrm{H}_{2} \mathrm{O}$ contents of low $\mathrm{MgO}$ high-alumina basalts, Contrib. Mineral. Petrol., 113, 167-184, 1993.

Sisson, T.W., and G.D. Layne, $\mathrm{H}_{2} \mathrm{O}$ in basalt and basaltic andesite glass inclusions from four subduction-related volcanoes, Earth and Planetary Science Letters, 117, 619-635, 1993.

Smolarkiewicz, P.K., A fully multidimensional positive definite advection transport algorithm with small implicit diffusion, J. Comp. Physics, 54, 325-362, 1983. 
Sparks, D.W., and E.M. Parmentier, Melt extraction from the mantle beneath mid-ocean ridges, Earth Planet. Sci. Lett., 105, 368-377, 1991.

Spiegelman, M., and D. McKenzie, Simple 2-D models for melt extraction at mid-ocean ridges and island arcs, Earth Planet. Sci. Let., 83, 137-152, 1987.

Tahirkheli, R.A.K., M. Mattauer, F. Proust, and P. Tapponnier, The India-Eurasia suture zone in northern Pakistan; synthesis and interpretation of recent data at plate scale, in Geodynamics of Pakistan, edited by A. Farah, and K.A. DeJong, pp. 125-130, Geological Survey of Pakistan, Quetta, Pakistan, 1979.

Tamura, Y., Y. Tatsumi, D. Zhao, Y. Kido, and H. Shukuno, Abstract T31F-07, Hot fingers in the mantle wedge: New insights into magma genesis in subduction zone, EOS, 82, F1174, 2001.

Tatsumi, Y., N. Ishikawa, K. Anno, K. Ishizaka, and T. Itaya, Tectonic setting of high-Mg andesite magmatism in the SW Japan Arc: K-Ar chronology of the Setouchi volcanic belt, Geophys. J. International, 144 (3), 625631, 2001.

Tatsumi, Y., M. Sakuyama, H. Fukuyama, and I. Kushiro, Generation of arc basalt magmas and thermal structure of the mantle wedge in subduction zones, J. Geophys. Res., 88, 5815-5825, 1983.

Treloar, P.J., Pressure-temperature-time paths and the relationship between collision, deformation and metamorphism in the north-west Himalaya, Geol. J., 30, 333-348, 1995.

Treloar, P.J., P.J. O'Brien, and M.A. Khan, Exhumation of early Tertiary, coesite-bearing eclogites from the Kaghan valley, Pakistan Himalaya, Abstracts: 16th HimalayaKarakorum-Tibet Workshop, Austria, in J. Asian Earth Sciences, 19, 68-69, 2001.

van Keken, P.E., B. Kiefer, and S.M. Peacock, High resolution models of subduction zones: Implications for mineral dehydration reactions and the transport of water into the deep mantle, G-cubed, in press, 2002.

White, R.S., D. McKenzie, and R.K. O'Nions, Oceanic crustal thickness from seismic measurements and rare earth element inversions, Journal of Geophysical Research, 97, 19,683-19,715, 1992.

Yamamoto, H., Contrasting metamorphic P-T-time paths of the Kohistan granulites and tectonics of the western Himalayas, J. Geol. Soc. London, 150, 843-856, 1993.

Yang, H.-J., R.J. Kinzler, and T.L. Grove, Experiments and models of anhydrous, basaltic olivine-plagioclase-augite saturated melts from 0.001 to $10 \mathrm{kbar}$, Contrib. Mineral. Petrol., 124, 1-18, 1996.

Yogodzinski, G.M., R.W. Kay, O.N. Volynets, A.V. Koloskov, and S.M. Kay, Magnesian andesite in the western Aleutian Komandorsky region: Implications for slab melting and processes in the mantle wedge, Geol. Soc. Amer. Bull., 107 (5), 505-519, 1995.

Yogodzinski, G.M., and P.B. Kelemen, Slab melting in the Aleutians: implications of an ion probe study of clinopyroxene in primitive adakite and basalt, Earth Planet. Sci. Lett., 158, 53-65, 1998.
Yogodzinski, G.M., J.M. Lees, T.G. Churikova, F. Dorendorf, G. Woeerner, and O.N. Volynets, Geochemical evidence for the melting of subducting oceanic lithosphere at plate edges, Nature, 409, 500-504, 2001.

Yogodzinski, G.M., O.N. Volynets, A.V. Koloskov, N.I. Seliverstov, and V.V. Matvenkov, Magnesian andesites and the subduction component in a strongly calc-alkaline series at Piip Volcano, Far Western Aleutians, J. Petrol., 35 (1), 163-204, 1994.

Yoshino, T., H. Yamamoto, T. Okudaira, and M. Toriumi, Crustal thickening of the lower crust of the Kohistan arc (N. Pakistan) deduced from Al-zoning in clinopyroxene and plagioclase, J. metamorphic Geol., 16, 729-748, 1998.

Zhao, D., and A. Hasegawa, P wave tomographic imaging of the crust and upper mantle beneath the Japan Islands, J. Geophys. Res., 98 (3), 4333-4353, 1993.

Zhao, D., and A. Hasegawa, Teleseismic evidence for lateral heterogeneities in the northeastern Japan arc, Tectonophysics, 237 (3-4), 189-199, 1994.

Zhao, D., A. Hasegawa, and S. Horiuchi, Tomographic imaging of $\mathrm{P}$ and $\mathrm{S}$ wave velocity structure beneath northeastern Japan, J. Geophys. Res., 97 (13), 19,90919,928, 1992a.

Zhao, D., S. Horiuchi, and A. Hasegawa, Seismic velocity structure of the crust beneath the Japan Islands, Tectonophysics, 212 (3-4), 289-301, 1992b.

Zhao, D., X. Yingbiao, D.A. Weins, L. Dorman, J. Hildebrand, and S. Webb, Depth extent of the Lau backarc spreading center and its relation to subduction processes, Science, 254-257, 1997.

Zhong, S., and M. Gurnis, Viscous flow model of a subduction zone with a faulted lithosphere: Long and short wavelength topography, gravity and geoid, Geophys. Res. Lett., 19, 1891-1894, 1992.

Peter B Kelemen, Dept. of Geology and Geophysics, Woods Hole Oceanographic Institution, Woods Hole, MA 02543. (peterk@whoi.edu)

Jennifer L. Rilling and E.M. Parmentier, Dept. of Geological Sciences, Brown University, Providence, RI 02912.

Luc Mehl and Bradley R. Hacker, Dept. of Geological Sciences \& Institute for Crustal Studies, University of California, Santa Barbara, CA 93106-9630. 


\section{FIGURE CAPTIONS}

Figure 1. Predicted geotherms beneath arcs from thermal modeling (small symbols and fine lines), compared to petrological estimates of PT conditions in the uppermost mantle and lowermost crust in arcs (large symbols and thick lines). Most petrological estimates are several hundred degrees hotter than the highest temperature thermal models at a given depth. Wide grey lines illustrate a plausible thermal structure consistent with the petrological estimates. Such a thermal structure requires adiabatic mantle convection beneath the arc to a depth of $50 \mathrm{~km}$, instead of minimum depths of $\sim 80 \mathrm{~km}$ or more in most thermal models.

\section{Petrological estimates for arc crust:}

Kohistan arc section, northern Pakistan: Chilas complex, lower crust (KC, [Jan, 1988; Jan and Howie, 1980] Kamila "amphibolites", lower crust (KK [Anczkiewicz and Vance, 2000; Yoshino et al., 1998; Jan and Karim, 1995; Yamamoto, 1993; Jan, 1988]. In addition, high P/T metamorphism is recorded by the Jijal complex, along the Main Mantle thrust at the base of the section (KJRAV [Anczkiewicz and Vance, 2000; Ringuette et al., 1999]; KJY [Yamamoto, 1993]) and by late veins in the Kamila amphibolites (KK veins [Jan and Karim, 1995]). This late, high $\mathrm{P} / \mathrm{T}$ is probably related to continental collision and exhumation of high $\mathrm{P}$ rocks along the Indian-Asian suture zone [e.g., Gough et al., 2001; Treloar et al., 2001; Treloar, 1995]. Oceanic Aleutian arc, Kanaga volcano xenoliths, base of crust? (AX [DeBari et al., 1987]). Talkeetna arc section, south-central Alaska: Tonsina area, garnet gabbros a few hundred meters above the Moho (TT [DeBari and Coleman, 1989] and this paper, Figure 3 and Table 1); and Klanelneechina klippe, lower crust (TK, this paper, Figure 3 and Table 1).

Petrological estimates of mantle-melt equilibration conditions:

NEJF, NE Japan arc front, and NEJC, NE Japan, central arc [Tatsumi et al., 1983]; SOC, southern Oregon Cascades [Elkins Tanton et al., 2001].

Thermal models with symbols:

Open squares and circles, NE Japan and Cascadia, nonlinear rheology [van Keken et al., 2002]; open diamonds and closed circles, $40 \mathrm{~km}$ and $70 \mathrm{~km}$ decoupling models, NE Japan [Furukawa, 1993a]; closed squares, fast subduction of thin plate, assuming mantle potential temperature of $1400^{\circ} \mathrm{C}$ [Kincaid and Sacks, 1997], heavy solid line with no symbols, isoviscous corner flow, NE Japan [van Keken et al., 2002].

\section{Other thermal models:}

NE and SW Japan [Peacock and Wang, 1999]; Izu-Bonin [Peacock, 2002]; Aleutians [Peacock and Hyndman, 1999]; $100 \mathrm{~km}$ decoupling model, NE Japan [Furukawa, 1993a]; slow subduction of thin plate, old plate and young plate, plus fast subduction of old plate and young plate, all assuming potential temperature of $1400^{\circ} \mathrm{C}$ [Kincaid and Sacks, 1997]; Alaska Range hot and cold models [Ponko and Peacock, 1995]; fast and slow subduction, with and without shear heating [Peacock, 1996]; general models [Peacock, 1990a]. Triangular grey field encloses geotherms inferred from heat flow data in the Oregon Cascades arc [Blackwell et al., 1982]; although interpretation of heat flow data is often controversial, the inferred geotherm is broadly consistent with metamorphic PT estimates for arc crust.

Figure 2. Schematic illustration of why petrological estimates of pressure and temperature for meta-plutonic rocks and mantle-melt equilibration do not have to lie along a steady state geotherm, and instead could represent temperature depth conditions for transient magma chambers and/or contact metamorphism. However, as argued in the text, seismic data suggest that high temperatures are present in the uppermost mantle and lowermost crust beneath arcs at steady state.

Figure 3. Peak metamorphic PT estimates for the lower crust of the Talkeetna arc section, south central Alaska (based on mineral core compositions in Table 1, with equilibria calculated using Thermocalc v. 3.1 and the May 2001 thermodynamic database). Ellipses with heavy lines are quartz-bearing samples from newly discovered garnet gabbros in the Klanelneechina klippe, about $50 \mathrm{~km} \mathrm{SW}$ of the Tonsina area. Ellipses with thin lines are for Tonsina area samples, from a thin layer of garnet gabbro immediately above the petrological Moho at the base of the arc section in the Tonsina area [DeBari and Coleman, 1989]; these lack quartz, so the PT estimates are based on a variety of equilibria involving amphibole as well as pyroxenes, plagioclase and garnet.

Figure 4. A. Illustration of the entire model domain with "steady state" isotherms and flow lines for model with $\mu_{\infty}$ of $10^{21} \mathrm{~Pa} \mathrm{~s}$ and $Q /\left(R T_{\infty}\right)$ of 20 . Prescribed subduction angle in all models is $45^{\circ}$. Subduction velocity is also prescribed. Dashed lines indicate position of temperature/depth sections in Figure 6. B, C. Viscosity contours and flow lines (white) for the upper righthand corner of a model with $\mu_{\infty}$ of $10^{18} \mathrm{~Pa}$ s and $Q /\left(R T_{\infty}\right)$ of 20 . Panel B shows an early time (2.6 Myr) with the thermal boundary layer in the overthrust plate increasing in thickness from $\sim 50 \mathrm{~km}$ on the right to $\sim 75 \mathrm{~km}$ adjacent to the subduction zone, and subduction initiating with a $\sim 75$ $\mathrm{km}$ thick plate. A dipping zone of weak nodes in the upper $50 \mathrm{~km}$ at the top of the subducting plate is used to model the presence of a fault zone (see text for discussion). Panel C illustrates the "steady-state" model (developed by about $15 \mathrm{Myr}$ ) after mechanical erosion of wedge corner due to entrainment of viscous mantle with the subducting plate. Time dependence arises from buoyantly-generated cold drips that form in the thermal boundary layer beneath the overthrust plate at a depth where the viscosity increases by about one order of magnitude (light blue) from the uniform temperature asthenosphere (dark blue). 
Figure 5. Temperature as a function of time at depths of 40 and $60 \mathrm{~km}$, at $\mathrm{x}=120 \mathrm{~km}$ where the subduction zone is $110 \mathrm{~km}$ below the surface, for models with 50 Myr old plate subducting at $60 \mathrm{~km} / \mathrm{Myr}$, and $\mu_{\infty}$ of $10^{18} \mathrm{~Pa} \mathrm{~s}$ (solid lines) and $10^{21} \mathrm{~Pa} \mathrm{~s}$ (dashed lines), both with $Q /\left(R T_{\infty}\right)$ of 20 . Temperatures increase dramatically in the first $\sim 10 \mathrm{Myr}$ of subduction, as the thermal boundary layer is thinned by viscous entrainment with the subducting plate, and then approach time-dependent, near steady-state values after several tens of Myr. In the model with $\mu_{\infty}$ of $10^{18} \mathrm{~Pa} \mathrm{~s}$, quasi-periodic density instabilities drive downwelling of relatively cold material from the base of the thermal boundary layer, reflected in the temperature fluctuations shown. Dripping of cold material from the base of the thermal boundary layer leads to generally higher shallow mantle temperatures in the model with $\mu_{\infty}$ of $10^{18} \mathrm{~Pa} \mathrm{~s}$, compared to that with $\mu_{\infty}$ of $10^{21} \mathrm{~Pa} \mathrm{~s}$.

Figure 6. Temperature contours, velocity vectors (white, scaled to subduction velocity of $60 \mathrm{~km} / \mathrm{Myr}$ ), and flow lines (black) for the upper lefthand corner of the model domain in Figure 4A after $20 \mathrm{Myr}$ of subduction (lefthand column) and $100 \mathrm{Myr}$ or more (righthand column). Temperatures are nearly steady state so that temperature distributions are almost identical in the two different columns. Top of subducting plate is indicated by the straight line to which streamlines of wedge flow converge. (A): $\mu_{\infty}=10^{21} \mathrm{~Pa} \mathrm{~s}$ and $Q /\left(R T_{\infty}\right)=0$ (isoviscous model) $(\mathbf{B}): \mu_{\infty}=10^{21} \mathrm{~Pa} \mathrm{~s}$ and $Q /\left(R T_{\infty}\right)=20 ;(\mathbf{C}): \mu_{\infty}$ of $10^{18} \mathrm{~Pa}$ and $Q /\left(R T_{\infty}\right)=20$. Note horizontal return flow into wedge for the isoviscous model (top), compared to diagonally ascending flow for temperature-dependent viscosity..

Figure 7. Steady-state temperatures (from the righthand column in Figure 6) in vertical sections where the top of the subducting plate is at a depths of 100 or $150 \mathrm{~km}$ (Panels A and C-F), and along the top of the subducting plate (Panel B). Panels A-E are for a subducting plate thermal thickness of $75 \mathrm{~km}(50 \mathrm{Myr})$ and a convergence rate of $60 \mathrm{~km} / \mathrm{Myr}$. Panel A shows selected results compared to constraints on arc temperature discussed in the text $(100 \mathrm{~km}$ sections in red, $150 \mathrm{~km}$ in blue). Thin lines are for isoviscous models with $\mu_{\infty}=10^{21} \mathrm{~Pa}$ s. Bold lines are for $\mu_{\infty}=10^{21}, 10^{18}$, and
$10^{17} \mathrm{~Pa}$ s, all with $Q /\left(R T_{\infty}\right)=20$. Clearly, a large variety of thermal models with temperature-dependent viscosity satisfy the constraints on arc lower crust and shallow mantle temperature. Panels B-F also show experimental, fluid-saturated solidii for sediment [Johnson and Plank, 1999; Nichols et al., 1994] and basalt [Lambert and Wyllie, 1972; Schmidt and Poli, 1998]. Panels C-E compare an isoviscous model with $\mu_{\infty}=10^{21} \mathrm{~Pa} \mathrm{~s}$ to models with different values of $\mu_{\infty}$ and $Q /\left(R T_{\infty}\right)$. Panel $\mathrm{C}$ emphasizes variation in activation energy in a section where the subducting plate is at $100 \mathrm{~km}$ depth, while panels D and E emphasize variation in "asthenospheric" viscosity in sections with subducting plate depth of 100 and $150 \mathrm{~km}$, respectively. Panel $\mathrm{F}$ shows the effect of varying subducting plate age and subduction velocity in a section with subducting plate depth of $100 \mathrm{~km}$. In Panel F, all cases have $\mu_{\infty}=10^{21} \mathrm{~Pa} \mathrm{~s}$, and all but the isoviscous case have $Q /\left(R T_{\infty}\right)=20$.

Figure 8. Comparison of heat flow from selected models with observed heat flow in NE Japan (data compiled by [Furukawa, 1993a]) and SW Oregon (digitized distances perpendicular to $100 \mathrm{~mW} / \mathrm{m}^{2}$ contour in Figure 2 of [Blackwell et al., 1982]. All distances are in $\mathrm{km}$ from the maximum observed or calculated heat flow. Models with temperature-dependent viscosity account for the high heat flow values observed at the arc and for the large variation in heat flow from the forearc to the maximum in the arc. The isoviscous model clearly does not explain these heat flow characteristics. Our models do not incorporate a realistic shallow plate geometry. Therefore the location of the trench and the dimensions of the forearc region are not well described in the models. For example, the distance from the "trench" to the heat flow maximum is only $\sim 50$ $\mathrm{km}$, whereas in most actual subduction zones, e.g. Oregon and Japan, it is much greater. The shallow plate geometry should not greatly affect the temperature distribution and flow pattern in the mantle wedge, which account for the high arc heat flow shown here. 
Table 1.

\begin{tabular}{llrcc}
\hline \multicolumn{1}{c}{ Sample } & \multicolumn{1}{c}{ Minerals } & \multicolumn{1}{c}{$\mathrm{T}\left({ }^{\circ} \mathrm{C}\right)$} & $\mathrm{P}(\mathrm{GPa})$ & \multicolumn{1}{c}{ Cor } \\
\hline 0713B07C & gar hb cpx opx plg & $982 \pm 108$ & $1.01 \pm 0.13$ & 0.46 \\
0713B07F & gar hb cpx plg & $954 \pm 92$ & $0.93 \pm 0.15$ & 0.26 \\
0731L01 & gar hb cpx opx plg & $1025 \pm 104$ & $1.07 \pm 0.14$ & 0.44 \\
1709L03A & gar hb cpx plg & $978 \pm 113$ & $1.00 \pm 0.19$ & 0.41 \\
1709L04 & gar hb cpx plg & $889 \pm 117$ & $0.83 \pm 0.19$ & 0.43 \\
1712P03 & gar opx cpx plg qz & $663 \pm 110$ & $0.63 \pm 0.14$ & 0.84 \\
1719P02 & gar opx qz & $692 \pm 141$ & $0.63 \pm 0.15$ & 0.70 \\
\hline
\end{tabular}

gar = garnet, $\mathrm{hb}=$ amphibole, $\mathrm{cpx}=$ clinopyroxene, $\mathrm{opx}=$ orthopyroxene, plg $=$ plagioclase,$q z=$ quartz, Cor $=$ correlation coefficient . 
Kelemen et al. 2002 Figure 1

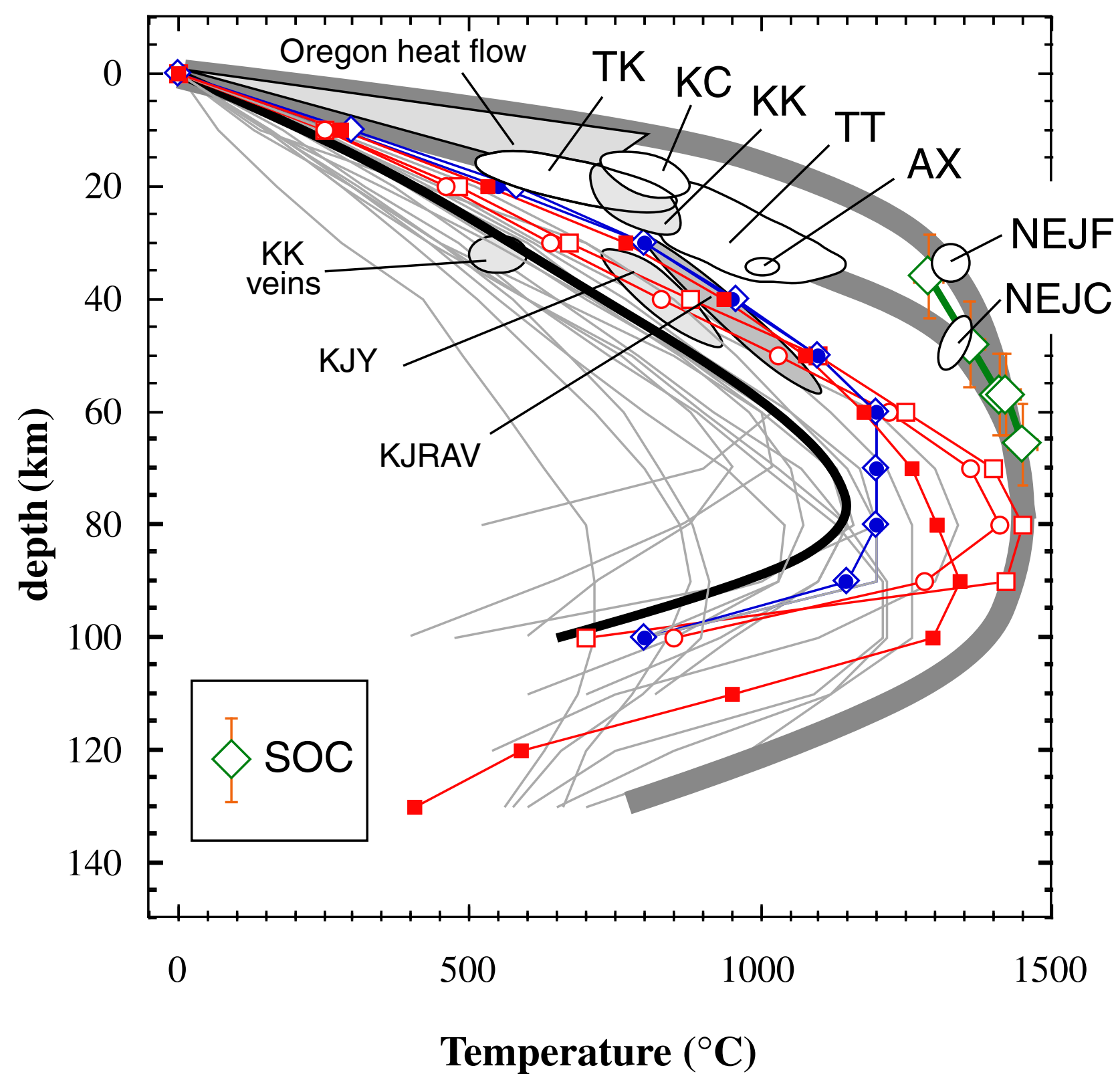


Kelemen et al. 2002

Figure 2

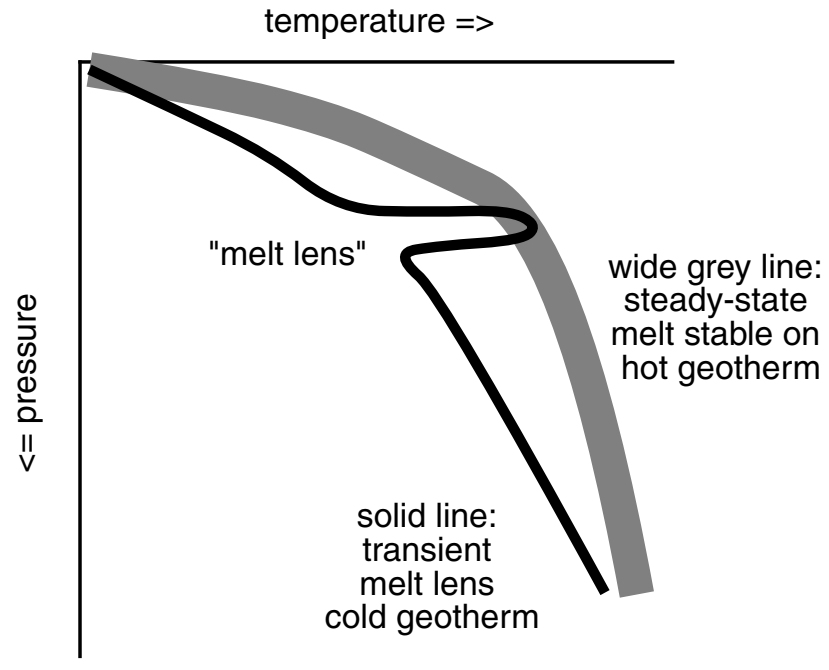


Kelemen et al., 2002, Figure 3

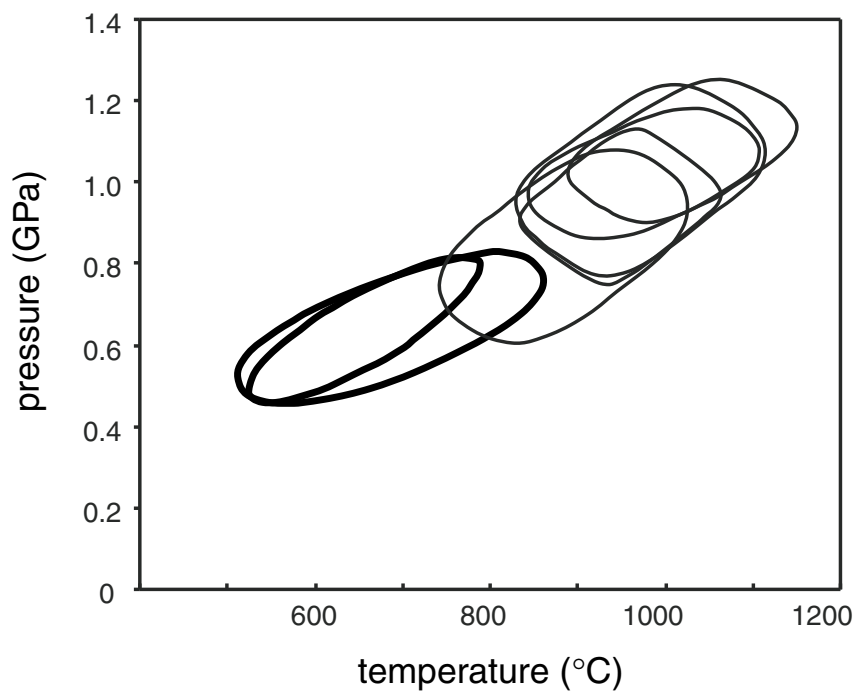



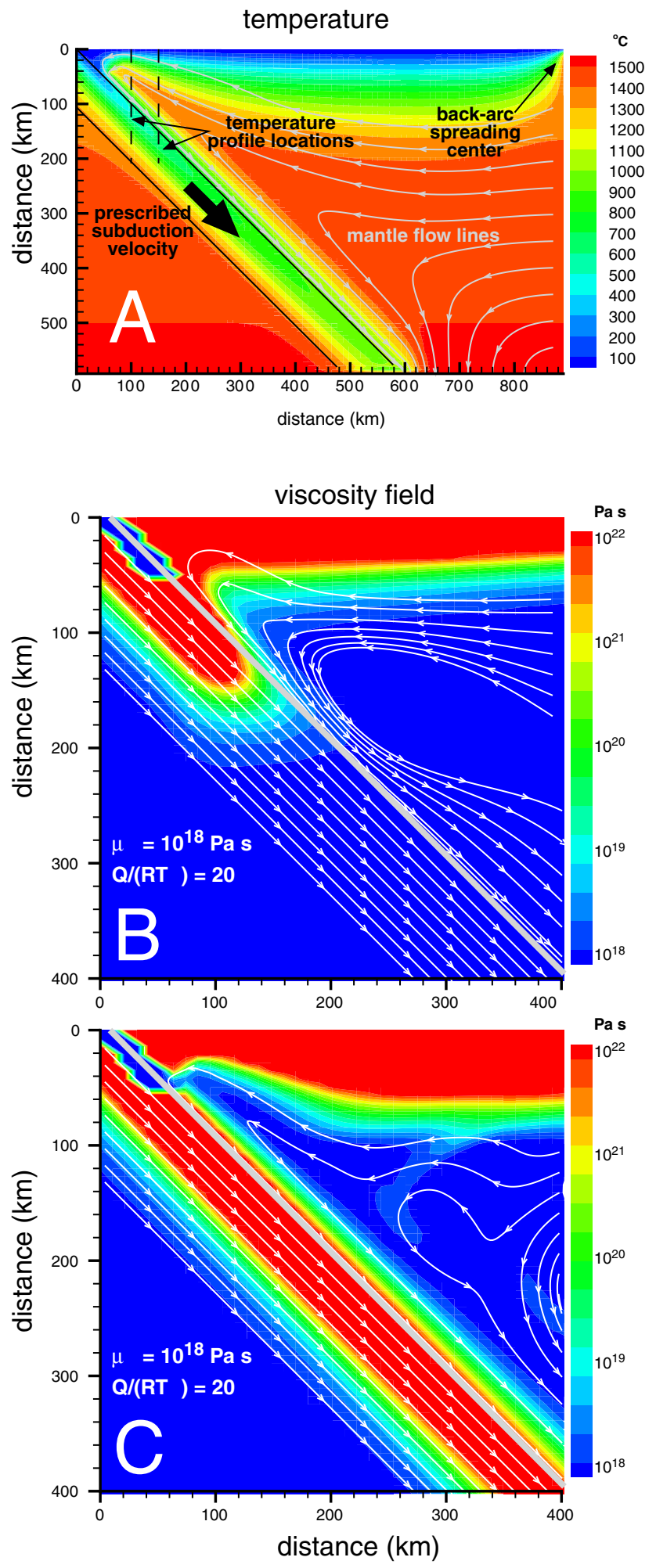
Kelemen et al., 2002, Figure 5

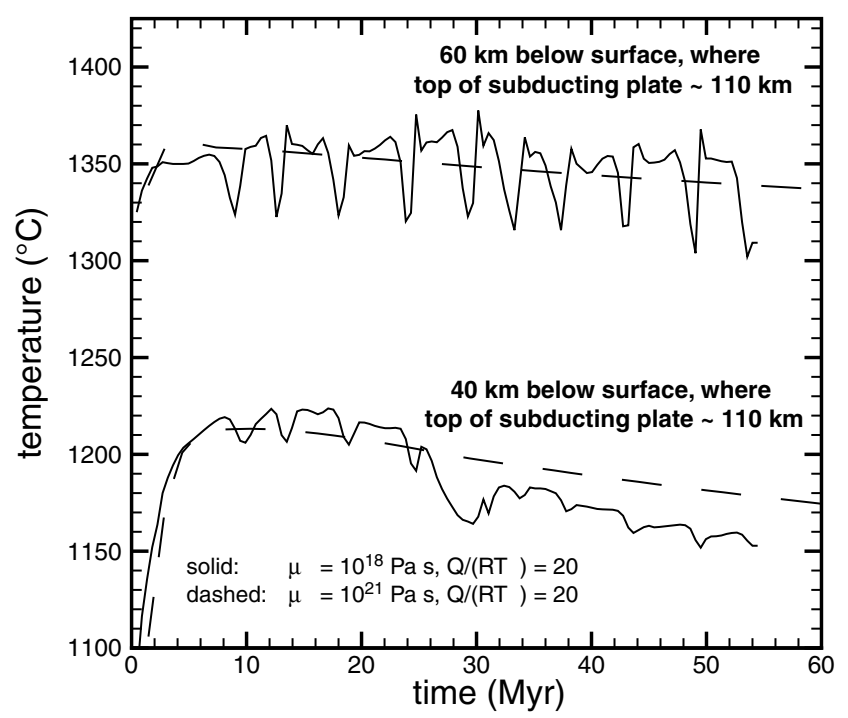



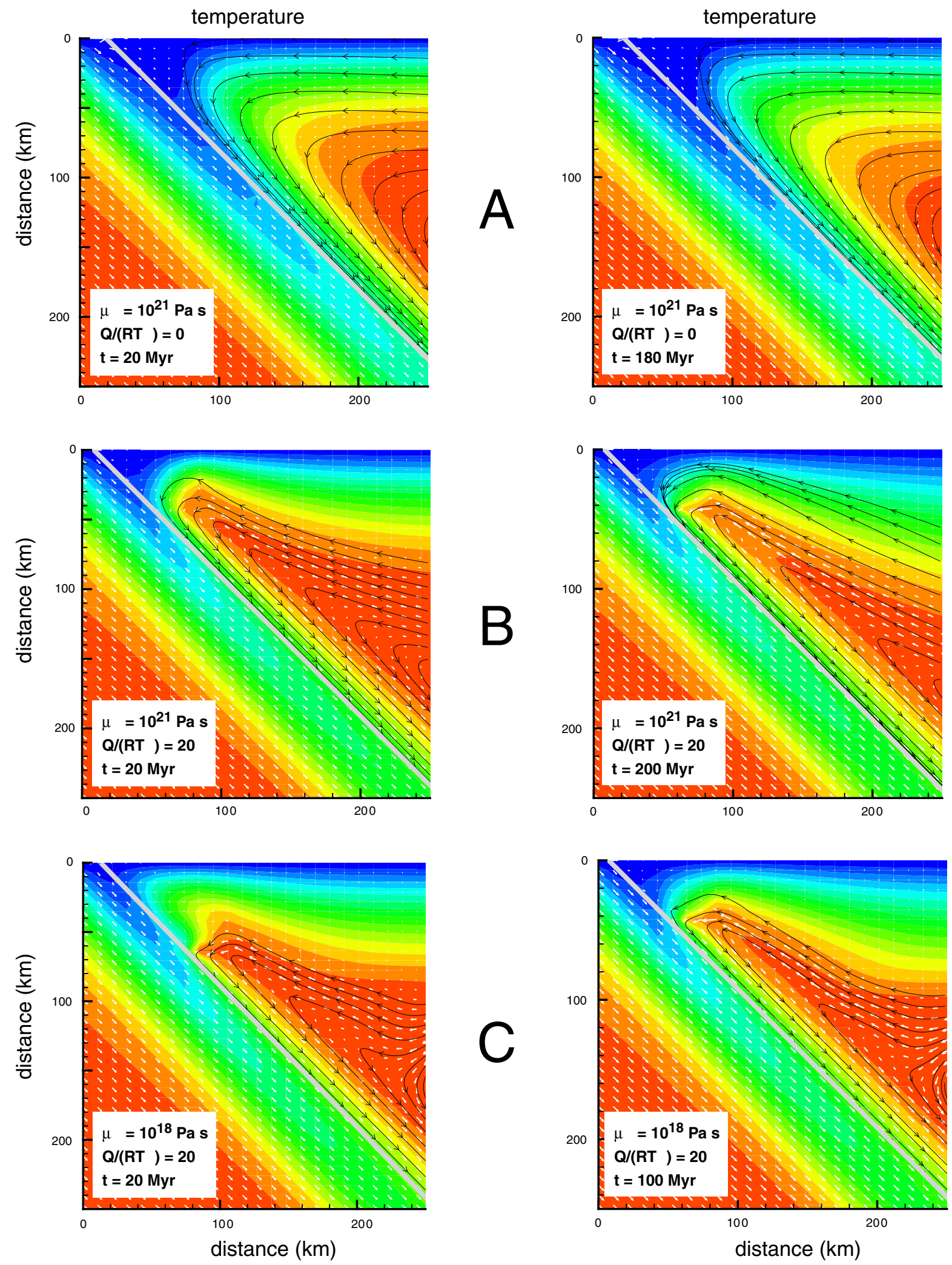

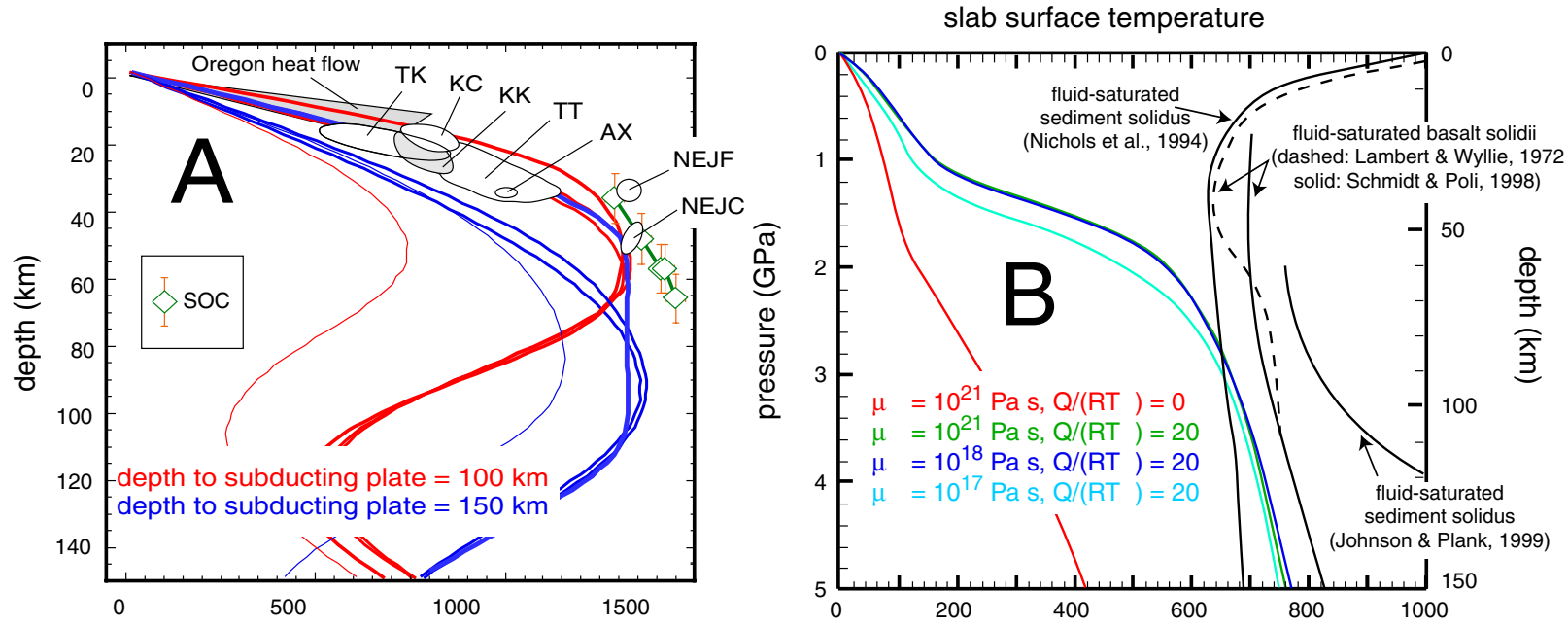

vertical temperature profiles where depth to subducting plate $=100 \mathrm{~km}$
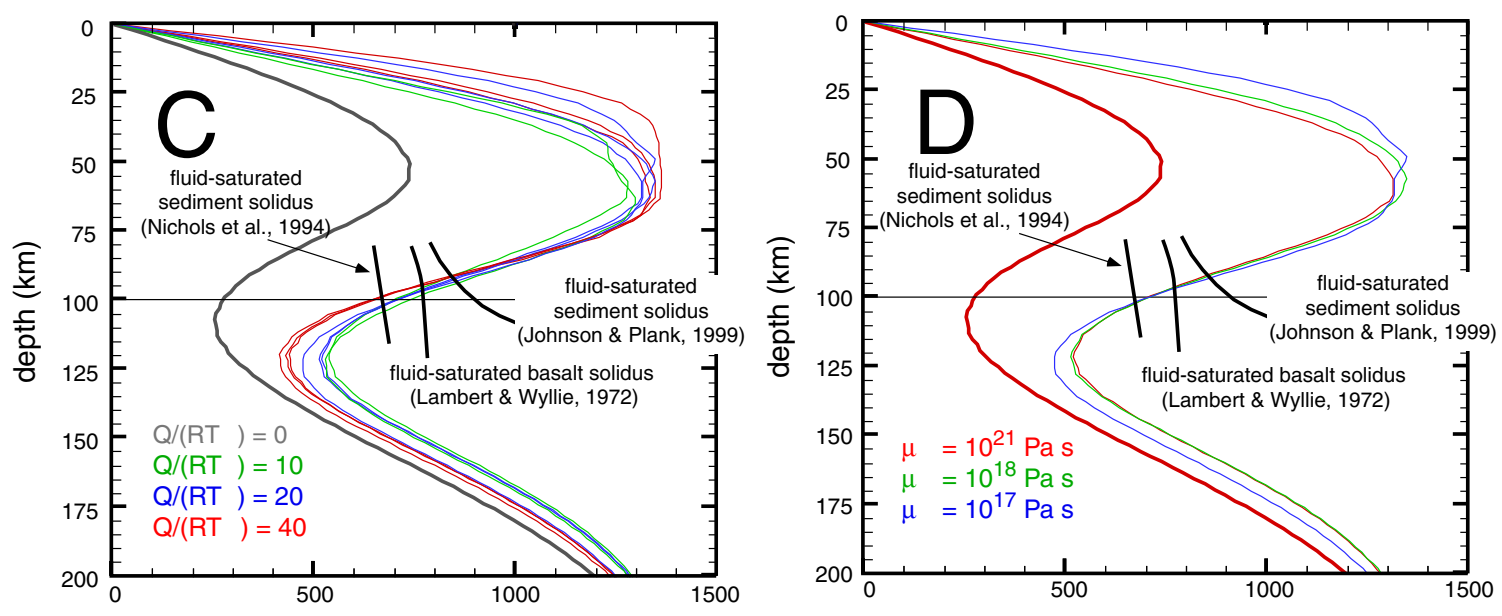

vertical temperature profiles where depth to subducting plate $=150 \mathrm{~km}$

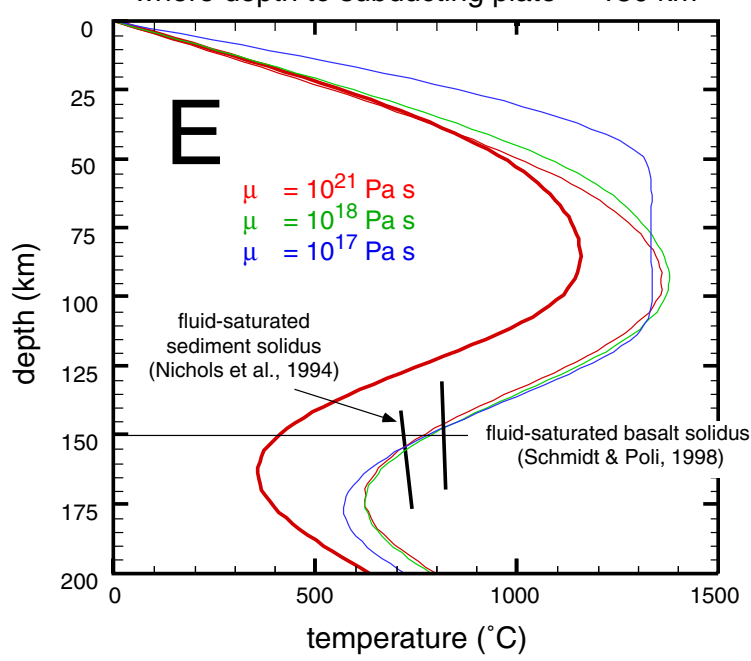

vertical temperature profiles where depth to subducting plate $=100 \mathrm{~km}$

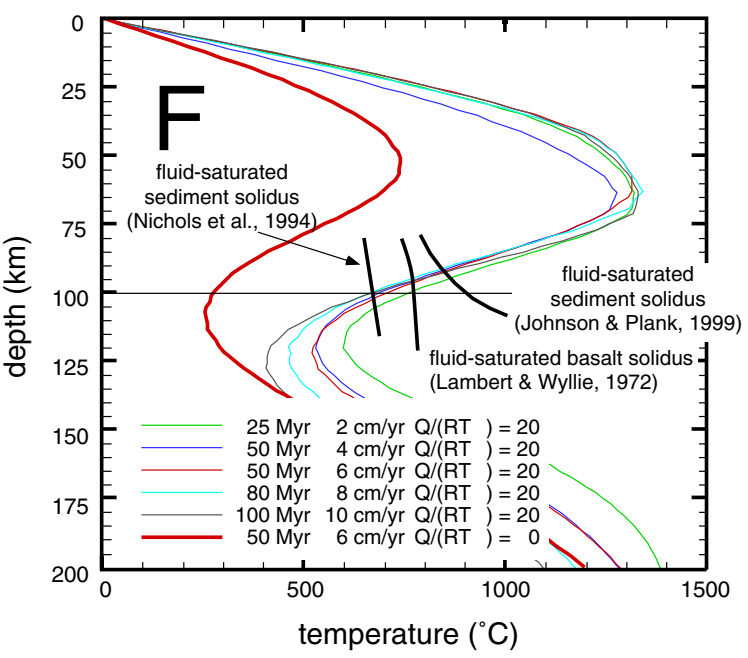




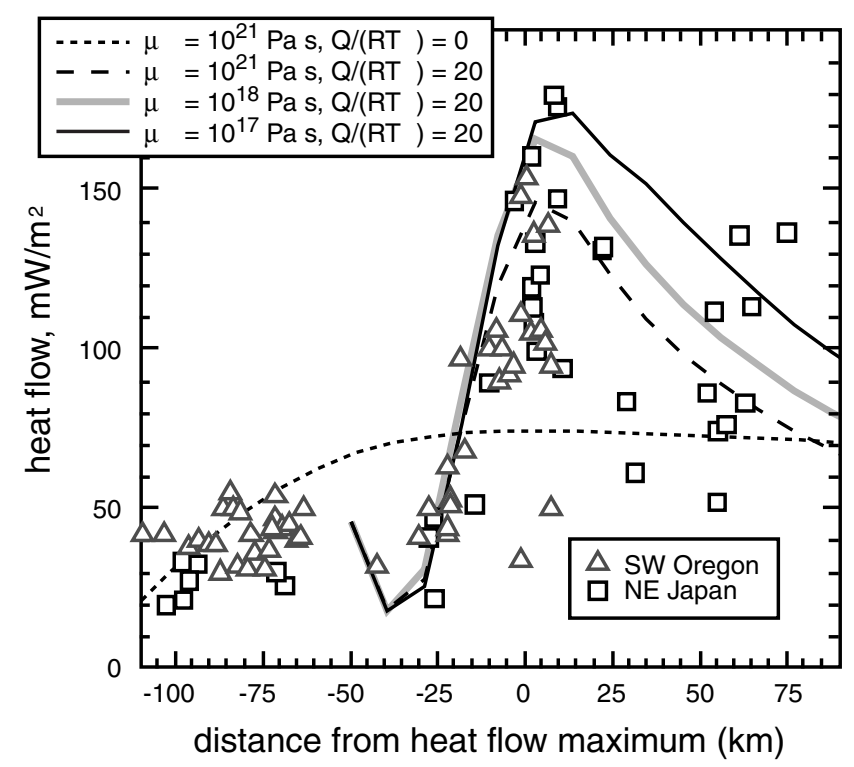

